\title{
Taming the Wild West of Arbitration Ethics
}

\author{
Kristen M. Blankley ${ }^{*}$
}

I. INTRODUCTION

In arbitration's perceived "anything goes" atmosphere, increasing concerns arise regarding ethical conduct within the forum. This concern is particularly valid given the extraordinarily limited review available after an arbitrator renders an award. ${ }^{1}$ Although a number of scholars

* Assistant Professor of Law, University of Nebraska College of Law. Thanks to all of those who read my drafts and commented on my presentations on this topic. Special thanks to Mark Weidenmaier, Richard Reuben, Cynthia DeBose, Stephen Ware, Christopher Drahozal, and Maureen Weston for their thoughtful comments and suggestions. Thanks to Justin Root for bringing this important topic to my attention. Thanks to my research assistant, Desireè Goff, for her wonderful help throughout this project.

1. Under the Federal Arbitration Act (FAA), a district court can vacate an award in any of the following limited circumstances:

(1) where the award was procured by corruption, fraud, or undue means;

(2) where there was evident partiality or corruption in the arbitrators, or either of them;

(3) where the arbitrators were guilty of misconduct in refusing to postpone the hearing, upon sufficient cause shown, or in refusing to hear evidence pertinent and material to the controversy; or of any other misbehavior by which the rights of any party have been prejudiced; or

(4) where the arbitrators exceeded their powers, or so imperfectly executed them that a mutual, final, and definite award upon the subject matter submitted was not made.

9 U.S.C. § 10(a) (2006).

The Uniform Arbitration Act—adopted by the vast majority of states—similarly allows for vacatur in the following events:

(1) The award was procured by corruption, fraud, or other undue means;

(2) There was evident partiality by an arbitrator appointed as a neutral or corruption in any of the arbitrators or misconduct prejudicing the right of any party;

(3) The arbitrators exceeded their powers;

(4) The arbitrators refused to postpone the hearing upon sufficient cause being shown therefor or refused to hear evidence material to the controversy or otherwise so conducted the hearing, contrary to the provisions of Section 5 , as to prejudice substantially the rights of a party; or

(5) There was no arbitration agreement and the issue was not adversely determined in proceedings under Section 2 and the party did not participate in the arbitration hearing without raising the objection; but the fact that relief was such that it could not or would not be granted by a court of law or equity is not ground for vacating or refusing to confirm the award. 
have commented on arbitrator misconduct, ${ }^{2}$ the literature is surprisingly devoid of commentary on the issue of attorney misconduct in the arbitral forum. In fact, codes of conduct for arbitrators have existed since the 1970s, ${ }^{3}$ but no similar standards have ever existed for arbitration participants. ${ }^{4}$ Attorney misconduct in the arbitral forum is an especially deep quagmire given the potential inapplicability of criminal penalties and sanctions commonly used in litigation to ensure that the attorneys act ethically, the witnesses testify truthfully, and the proper evidence remains available. ${ }^{5}$

UNIF. ARBITRATION ACT § 12(a) (1956).

The Revised Uniform Arbitration Act—adopted by a handful of states—provides a similar, but expanded, set of review provisions, including the review for "corruption, fraud, or other undue means.” REVISED UNIF. ARBITRATION ACT § 23(a) (2000).

2. See, e.g., Michael H. LeRoy, Are Arbitrators Above the Law? The "Manifest Disregard of the Law" Standard, 52 B.C. L. REv. 137 (2011) (arguing that the Supreme Court should affirm "manifest disregard" as a ground for vacatur in the United States); Margaret L. Moses, Arbitration Law: Who's In Charge?, 40 Seton Hall L. REv. 147 (2010) (arguing that recent Supreme Court precedent, which limited judicial review of arbitration awards, undermines the statutory protections of the FAA); Neal R. Troum, Another View of Rent-A-Center, Arbitration and Arbitrability: Who is Watching the Watchmen?, 28 ALtS. TO THE HIGH COST OF LiTIG. 184, 184-85 (2010) (discussing lack of oversight for arbitrators); Darren P. Lindamood, Comment, Redressing the Arbitration Process: An Alternative to the Arbitration Fairness Act of 2009, 45 WAKE FOREST L. REV. 291 (2010) (arguing that arbitration reform should principally address and provide meaningful judicial review); Sara Roitman, Note, Beyond Reproach: Has the Doctrine of Arbitral Immunity Been Extended Too Far for Arbitration Sponsoring Firms?, 51 B.C. L. REV. 557 (2010) (discussing conflict of interest concerns for private arbitration firms that administer arbitration proceedings for their large corporate clients).

3. See Am. BAR Ass'n \& AM. ARbitration Ass'N, Code of Ethics For ARbitrators in COMMERCIAL DISPUTES (2004), available at http://www.americanbar.org/content/dam/aba/ migrated/dispute/commercial_disputes.authcheckdam.pdf. In 1977, the American Bar Association (ABA) and the American Arbitration Association (AAA) jointly created the Code of Ethics for Arbitrators in Commercial Disputes, which was a comprehensive and well regarded set of standards for arbitrators. Id. In 2004, the ABA and the AAA updated the Code of Ethics to reflect the changing nature of arbitration practice, particularly in consumer and employment arbitration. Id. "The use of arbitration to resolve a wide variety of disputes has grown extensively and forms a significant part of the system of justice on which our society relies for a fair determination of legal rights. Persons who act as arbitrators therefore undertake serious responsibilities to the public, as well as to the parties." Id. Of course, these provider rules do not have the force of law, but many courts use them as guidance on issues of arbitrator conduct. See, e.g., Merit Ins. Co. v. Leatherby Ins. Co., 714 F.2d 673, 678-79 (7th Cir. 1983) (discussing what the Code of Ethics requires), amended by 728 F.2d 943 (7th Cir. 1984).

4. As noted in Part III, the 2002 changes to the Model Rules of Professional Conduct now explicitly apply to attorneys engaged in arbitration practice. See MODEL RULES OF PROF'L CONDUCT R. 1.0(m) (2003) (including representation before an arbitral tribunal as part of the definition of "tribunal"). These rules, of course, only apply to attorneys and not to other arbitration participants. Other common rules of litigation ethics-regarding perjury, suborning perjury, document tampering, or document destruction—have not yet been extended to arbitration. See infra Part III.

5. See infra Part III. The "proper amount" of evidence is a looser concept in arbitration as 
These ethical concerns permeate popular media, as well as case law. For instance, in 2007, the Financial Industry Regulatory Authority (FINRA) issued \$12.5 million in sanctions against Morgan Stanley for intentionally withholding e-mail evidence from arbitration claimants and falsely claiming that the e-mail communications had been destroyed in the September 11, 2001 terrorist attacks on the World Trade Center. ${ }^{6}$ Morgan Stanley, in fact, preserved the e-mails on back-up tapes stored at another location. $^{7}$ Nine-and-a-half million dollars of the settlement would be distributed among "several thousand customers" with open cases during the relevant time frame. ${ }^{8}$ For the same transgressions, Morgan Stanley suffered a $\$ 1.4$ billion jury verdict. ${ }^{9}$ Arguably, Morgan Stanley only incurred arbitration penalties because of its association with FINRA and not because the law required such sanctions.

More recently, questions have arisen regarding Floyd Landis and his testimony under oath in a doping arbitration. ${ }^{10}$ Landis won the 2006 Tour de France after falling behind in Stage Sixteen, only to rally to a miraculous comeback in Stage Seventeen of the Tour. ${ }^{11}$ Following the race, the International Cycling Union - the governing body for cyclingconfirmed that Landis tested positive for performance enhancing drugs in violation of anti-doping rules. ${ }^{12}$ Landis denied taking any illegal substances and challenged the allegations in an arbitration against the United States Anti-Doping Agency under the World Anti-Doping Code. $^{13}$ Landis engaged in a public arbitration of epic proportion to

opposed to litigation. Arbitration is not necessarily bound by any particular rules of procedure, much less the Federal Rules of Civil Procedure. As discussed in Part III, the ethical rules for attorneys set minimum standards with respect to document destruction. These ethical rules, however, only apply to attorneys and not necessarily clients or pro se parties.

6. News Release, FINRA, Morgan Stanley to Pay \$12.5 Million to Resolve FINRA Charges that It Failed to Provide Documents to Arbitration Claimants, Regulators (Sept. 27, 2007), available at http://www.finra.org/newsroom/newsreleases/2007/p037071.

7. Id.

8. Id.

9. Richard L. McConnell et al., Discovery of Electronic Information: The Scylla of Excessive Cost and the Charybdis of Potential Sanctions, METRO. CORP. Couns., Oct. 2006, at 52, available at http://www.metrocorpcounsel.com/articles/7380/discovery-electronic-information-scylla-excessivecost-and-charybdis-potential-sanctio.

10. See Amy Shipley, After Tour, Armstrong May Face Another Obstacle, WASH. Post, July 18, 2010, at D01.

11. Maureen Weston, Anatomy of the First Public International Sports Arbitration and the Future of Public Arbitration After USADA v. Floyd Landis, 2 Y.B. ON ARB. \& MED., 234, 234-35 (2010).

12. Id. at 235.

13. See id. at 236-37. At the time, the USADA had never lost a doping case to an athlete. Id. at 236. Unlike standard procedure, Landis requested that his hearings be public. Id. at 237. The 
defend his alleged innocence. ${ }^{14}$ After a multi-day hearing, Landis lost by a $2-1$ decision. $^{15}$ More than two years after the announcement of the decision, Landis admitted to using banned substances, detailing "extensive, consistent use of the red blood cell booster erythropoietin (commonly known as EPO), testosterone, human growth hormone and frequent blood transfusions, along with female hormones and a one-time experiment with insulin, during the years he rode for the U.S. Postal Service and Switzerland-based Phonak teams."

Despite the admission of lying under oath at arbitration, no serious inquiry has been conducted as to whether Landis committed perjury in the arbitral forum. ${ }^{17}$ In stark contrast, consider the testimony of Barry Bonds before a grand jury regarding whether he ever used performance enhancing drugs. Bonds vehemently denied taking steroids under oath. ${ }^{18}$ Now that baseball's steroid scandal is in the public light, Bonds has stood trial for his testimony before the grand jury. ${ }^{19}$ As will be discussed in more detail, the current state of perjury laws helps explain why these two otherwise similar situations were handled so differently. ${ }^{20}$

This Article considers whether the current law and arbitral mechanisms effectively curb parties and attorneys from committing acts simply not tolerated in litigation. Part II considers why this problemthe disconnect between litigation and private adjudication - has arisen in the first place. Part III analyzes the perjury, tampering, and spoliation

USADA rules specifically allow for such a public procedure. AM. ARBITRATION Ass'N, SUPPlEMENTARY PROCEDURES FOR the ARBITRATION OF OlyMPIC SPORT DOPING DiSPUTES R. 4 (2004), available at http://www.adr.org (click "Rules \& Procedures," then search for "Olympic") (allowing an athlete to request a public hearing).

14. Weston, supra note 11, at 237-35. The arbitration process included arbitrator selection issues, many discovery rulings, and a public hearing. Id. In addition, Landis engaged in an Internet campaign to rally support for himself-both financially and in terms of public opinion. See id. at 247-49 (describing Landis's Wiki Defense Strategy).

15. Id. at 277 .

16. Bonnie D. Ford, Landis Admits Doping, Accuses Lance, ESPN.COM (May 21, 2010), http://sports.espn.go.com/oly/cycling/news/Story?id=5203604.

17. Dale Robertson, Lance Armstrong Doping Probe Ends With No Charges, Hous. CHRON. Feb. 3, 2012, at A1 ("Landis wasn't subpoenaed by the grand jury, either").

18. Timeline: Barry Bonds and Steroid Allegations, NEWSDAY (Dec. 16, 2011, 3:09 PM), http://www.newsday.com/sports/baseball/timeline-barry-bonds-and-steroid-allegations-1.3394535.

19. United States v. Bonds, No. CR07-00732 SI, slip op. at 1 (N.D. Cal. Aug. 26, 2011). The jury convicted Bonds of obstruction of justice. Id. Roger Clemens also faces perjury charges for statements made before Congress based on his own steroid use. Lester Munson, Roger Clemens' Perjury Retrial Begins, ESPN.COM (Apr. 16, 2012), http://espn.go.com/espn/otl/story/_/id/7817965/ roger-clemens-returns-court-retrial-perjury-charges.

20. See infra Part II (discussing the disconnect between litigation and private arbitration rules on perjury). 
laws across the country, determining that, with the exception of attorney ethics rules, these traditional litigation rules, criminalizing certain conduct before a court, do not extend to the same actions in arbitration. Part III also discusses five major reasons why the perjury and tampering laws should be extended to the arbitral forum. These reasons include the changing nature of arbitration over the course of the last four decades, the treatment of arbitration as a quasi-judicial forum, the application of immunity to arbitration participants, the failure of arbitration providers to regulate the conduct of arbitration participants, and the limited judicial review available to parties in arbitration - especially when those parties challenge the arbitration award as having been procured by fraud. Ultimately, this Article suggests making a simple legislative change that would extend the perjury and tampering laws to the arbitral forum. The proposed legislative change would mirror a change already made in the attorney ethics rules extending the definitions of "tribunal" and "official proceedings" to explicitly include arbitration. Through these simple definitional changes, the perjury and tampering laws would explicitly apply to the arbitral forum.

\section{ARbitration AS A “CREAtURe OF CONTRACT” AND PRIVATE ADJUDICATION}

The arbitration process consists of parties who voluntarily submit their dispute to a third-party decision maker who adjudicates the dispute on its merits. ${ }^{21}$ Courts and commentators alike refer to arbitration as a "creature of contract," therefore addressing any number of issues arising in the arbitration with contract principles. ${ }^{22}$ Arbitration as a contractual

21. Sarah Rudolph Cole \& Kristen M. Blankley, Arbitration, in THE HANDBOOK OF DisPUTE RESOlUtion 318, 318-19 (Michael L. Moffitt \& Robert C. Bordone eds., 2005).

22. This idea is firmly rooted in the FAA, which enforces agreements to arbitrate and treats them like any other contract. 9 U.S.C. $\S 2$ (2006); see also MyLinda K. Sims \& Richard A. Bales, Much Ado About Nothing: The Future of Manifest Disregard After Hall Street, 62 S.C. L. REV. 407, 410 (2010) ("[Section 2] also establishes that arbitration is a creature of contract law and that arbitrational provisions should be viewed in this light.”). For example, courts use this language to determine whether the parties ever consented to the arbitral process. See, e.g., United Steelworkers v. Am. Mfg. Co., 363 U.S. 564, 570-71 (1960) (Brennan, J., concurring) ("To be sure, since arbitration is a creature of contract, a court must always inquire, when a party seeks to invoke its aid to force a reluctant party to the arbitration table, whether the parties have agreed to arbitrate the particular dispute.”). Courts also consider contractual intent when determining whether the arbitrator acted within his or her powers. See Puleo v. Chase Bank USA, N.A., 605 F.3d 172, 194 (3d Cir. 2010) ("As we have stressed, '[a]rbitration is fundamentally a creature of contract, and an arbitrator's authority is derived from an agreement to arbitrate.”” (quoting Allstate Settlement Corp. v. Rapid Settlements, Ltd., 559 F.3d 164, 169 (3d Cir. 2009))); Edstrom Indus., Inc. v. Companion 
agreement is well rooted in federal and state arbitration law. ${ }^{23}$ Arbitration simply does not exist without the consent of the parties involved. ${ }^{24}$

By law, courts generally limit their involvement in the arbitral process. $^{25}$ The primary purposes of the Federal Arbitration Act (FAA) and the Uniform Arbitration Act (UAA) are to enforce written agreements to arbitrate ${ }^{26}$ and to give parties the right to enforce arbitration awards as if they were judgments of a court, ${ }^{27}$ provided that the award is not vacated under the limited grounds allowed by law. ${ }^{28}$ Outside of these two circumstances—sometimes called the "front-end"

Life Ins. Co., 516 F.3d 546, 552 (7th Cir. 2008) ("But precisely because arbitration is a creature of contract, the arbitrator cannot disregard the lawful directions the parties have given them. If they tell him to apply Wisconsin law, he cannot apply New York law."), abrogation recognized by Affymax, Inc. v. Ortho-McNeil-Janssen Pharms., Inc., 660 F.3d 281 (7th Cir. 2011); Scott D. Marrs \& Sean P. Milligan, What You Always Wanted to Know About Arbitration: Five Arbitration Issues Recently Decided by the Courts, 73 TEX. B. J. 634, 634 (2010) ("Because arbitration is a creature of contract, the rights and obligations of the parties and the arbitrators are, to an important extent, borne out of the arbitration clause itself."). Courts invoke this phrase also when determining who, in fact, is bound to arbitrate. See, e.g., Dunmire v. Schneider, 481 F.3d 465, 467 (7th Cir. 2007) ("Arbitration is a creature of contract, as Dunmire stresses, but the party to be bound here is Dunmire himself: his signature is on the contract.”).

23. See 9 U.S.C. $\S 2$ ("A written provision in any ... contract evidencing a transaction involving commerce to settle by arbitration a controversy thereafter arising out of such contract... shall be valid, irrevocable, and enforceable, save upon such grounds as exist at law or in equity for the revocation of any contract.”); see also UNIF. ARBITRATION ACT § 1 (1956) (“A written agreement to submit any existing controversy to arbitration or a provision in a written contract to submit to arbitration any controversy thereafter arising between the parties is valid, enforceable and irrevocable....”). This language, essentially, puts agreements to arbitrate on equal footing with other contracts and is intended to reverse judicial hostility toward agreements to arbitrate, which —at the time Congress passed the FAA in 1925-were considered "executory" contracts not enforceable by specific performance. STEPHEN J. WARE, PRINCIPLES OF Alternative DisPUTE RESOlUtion 23 (2d ed. 2007).

24. This Article recognizes a small minority of disputes subject to arbitration by law. When arbitration is mandated by law-as opposed to by contract - the arbitration procedure must usually be non-binding to preserve the parties' Seventh Amendment right to a trial by jury. WARE, supra note 23, at 19-20. In the case of contractual arbitration, parties are free to waive their Seventh Amendment rights to participate voluntarily in the arbitral process. See Am. Heritage Life Ins. Co. v. Orr, 294 F.3d 702, 711 (5th Cir. 2002) ("The Seventh Amendment does not confer the right to a trial, but only the right to have a jury hear the case once it is determined that the litigation should proceed before a court. If the claims are properly before an arbitral forum pursuant to an arbitration agreement, the jury trial right vanishes.” (citing Cremin v. Merrill Lynch, Pierce, Fenner \& Smith, Inc., 957 F. Supp. 1460, 1471 (N.D. Ill. 1997)).

25. See supra note 1 (discussing courts' limited review of the arbitral process).

26. See supra note 23.

27. Section 9 of the FAA provides that any party to an arbitration can apply to the court to enter judgment upon the award such that the award becomes an order of the court. 9 U.S.C. § 9; see also Unif. ARbitration ACt § 11 (1956); ReVISED Unif. ARbitration ACt § 22 (2000).

28. See supra note 1 (discussing courts' limited review of the arbitral process). 
and the "back-end" of arbitration — courts largely refrain from interfering in the arbitral process. ${ }^{29}$

Courts rightly do not, generally, interfere in the arbitral process, thus giving effect to the parties' contractual agreement. After all, giving effect to the parties' agreement to arbitrate necessarily means that the courts should have a hands-off approach during the arbitral process. ${ }^{30}$ These parties have voluntarily relinquished their right to a trial by jury ${ }^{31}$ and agreed to have their current or future dispute ${ }^{32}$ resolved by a thirdparty arbitrator. Arbitrators, for the most part, are competent to handle the disputes presented to them, even complex questions of law. ${ }^{33}$

Thus, arbitration has a natural—and contractual—independence from the judicial process. This independence helps account for some of the primary benefits of arbitration, including confidentiality, cost and time efficiencies, informality, finality, and the ability of the parties to continue a working relationship with each other after the arbitrator resolves the dispute. $^{34}$ These benefits flow from arbitration's disconnect from the

29. The FAA, UAA, and Revised Uniform Arbitration Act (RUAA) provide for some limited involvement by courts in arbitration, such as assisting in appointing an arbitrator, 9 U.S.C. § 5; UNIF. ARbitration ACT $\S 3$ (1956); REVISED UNIF. ARBITRATION ACT $\S 11$ (2000), or providing a subpoena power to compel witnesses to testify at an arbitration. 9 U.S.C. § 9; UNIF. ARBITRATION ACT § 7; REVISED UnIF. ARBITRATION ACT § 17. Otherwise, courts are generally not available to interfere until the arbitral process is over. The RUAA also gives courts the ability to order provisional remedies to the parties to the arbitration if an arbitrator has not yet been appointed at the time that the need for such provisional remedies arises. REVISED UNIF. ARBITRATION ACT $\S 8$.

30. Of course, this statement does not extend to the lawful role of courts regarding enforcement and arbitrability issues and in determining whether an award should be vacated or confirmed.

31. See supra note 24 (discussing the waiver of the Seventh Amendment right to a jury trial).

32. Often, arbitration agreements are "pre-dispute" contracts, meaning that the parties contracted in advance to resolve any dispute by binding arbitration. For example, two businesses in a long-term relationship might include as part of their contract that they agree to resolve any disputes arising under the contract by arbitration in order to take advantage of the speed, efficiency, and flexibility of arbitration - particularly given the parties' relationship with one another. The practice is now commonplace in employment agreements and many consumer agreements as well, although it is significantly more controversial than pre-dispute arbitration agreements between businesses. See Jean R. Sternlight, Creeping Mandatory Arbitration: Is It Just?, 57 STAN. L. REV. 1631, 163132 (2005).

33. For many years, the Supreme Court expressed skepticism of an arbitrator's abilities to decide questions of law. See Wilko v. Swan, 346 U.S. 427, 435-37 (1953) (expressing doubt that questions under the Securities Act could be expertly resolved by arbitrators, as opposed to judges), overruled by Rodriguez de Quijas v. Shearson/Am. Express, Inc., 490 U.S. 477 (1989). The Court ultimately overruled Wilko in Rodriguez, holding that arbitrators are capable of determining complex issues of law in the area of securities. 490 U.S. at 486. The Rodriguez decision followed Mitsubishi v. Soler Chrysler-Plymouth, Inc., in which the Supreme Court held that arbitrators are competent to handle complex antitrust cases. Id. at 482 (discussing Mitsubishi). Shortly after Rodriguez, the Court decided Gilmer v. Interstate/Johnson Lane Corp., holding that arbitration of a case under the Age Discrimination in Employment Act was appropriate. 500 U.S. 20, 35 (1991).

34. Cole \& Blankley, supra note 21, at 318-19. For example, arbitration has flexible and 
more "traditional" and rights-based adjudication in the state and federal courts in the United States. ${ }^{35}$

This disconnect, while largely beneficial for arbitration participants, breeds the possibility of abuse. Without judicial oversight, or even significant recourse to the judicial system, the standards of ethical participation in the arbitral forum become blurred. What incentives exist for arbitration participants to tell the truth, to preserve relevant documents-especially harmful documents—or to ensure that witnesses are available to testify at the arbitration hearing? As explained in Part III, traditional litigation rules, such as those related to perjury, witness tampering, and document destruction, likely do not apply to the arbitration forum. Making the situation worse, courts will consider vacating an arbitral award because of alleged improper conduct on the part of parties or witnesses using an inexplicably more burdensome standard of review than is used to review other types of errors. ${ }^{36}$

Simple legislative changes discussed in Part III can make the arbitral process fairer for participants in situations involving abuse of the arbitral process. Making these small changes could have a drastic impact on the perception of arbitration as a fair process, ${ }^{37}$ while hopefully encouraging participants to act within ethical boundaries and creating more respect for the arbitral process.

informal procedures compared to traditional, civil litigation in the United States. Arbitral hearings often occur in conference rooms, not courthouses. Hearings occurring over multiple days may not occur consecutively if scheduling the hearing over time is advantageous to the parties or the arbitrator. Arbitrators also have greater involvement in the merits' presentation compared to judges, often engaging in witness questioning and asking for additional information of attorneys.

35. This Article is limited to a discussion of arbitrations occurring within the United States. International arbitration involves a whole host of ethics issues not covered in this Article.

36. See infra Part III.C.6. Courts can review arbitration awards for "fraud," and most challenges for fraud involve a showing of fraud by "clear and convincing” evidence. See Bonar v. Dean Witter Reynolds, Inc., 835 F.3d 1378, 1383 (11th Cir. 1988). No other arbitral review contains this heightened standard. As discussed in Part III.C.6, this standard is out of line with other avenues for review and should be eliminated to prevent ethical abuses and to keep the review for "fraud" in line with other avenues of review for arbitration.

37. Currently, arbitration's reputation is sullied as an unfair forum. The primary criticism of arbitration has been that arbitrators are biased in favor of large companies and employers who are "repeat players" in arbitration — and who often pay for the arbitrator fees-at the cost of one-time players, such as employees and consumers. See Sarah R. Cole \& Kristen M. Blankley, Empirical Research on Consumer Arbitration: What the Data Reveals, 113 PENN ST. L. REV. 1051, 1059-60 (2009) (analyzing data on consumer arbitrations released by the National Forum of Arbitration). Some of these criticisms seem to have tainted the perception of arbitration as a whole. 


\section{QUESTIONABLE PRACTICES IN ARBITRATION AND WHETHER “COURT”-DESIGNED RULES APPLY}

Although the limited role of courts in the arbitral process creates many efficiencies, this same disconnect also creates certain ethical loopholes in the administration of justice. This section considers whether perjury statutes and ethical rules apply to the forum of arbitration and considers what rules exist to preserve evidence for arbitration. This section concludes by noting how these fundamental ethical rules generally to not extend to the arbitral forum, outside of the context of attorney misconduct. Therefore, this section advocates simple legislative changes to create a fairer playing field in arbitration and real repercussions for those arbitral parties who abuse the process.

\section{A. Why Perjury Laws Generally Do Not Apply to Arbitral Proceedings}

This section seeks to answer a relatively straightforward question: Do perjury laws and ethical rules apply to arbitration at all? Surprisingly, a fifty-state survey of perjury laws reveals that these laws do not, in fact, apply to arbitration-or at least not by their plain language. By contrast, however, the attorney ethics rules do prohibit attorneys from suborning perjury, but no consequences appear to befall a lying witness. Similarly, a fifty-state survey of document destruction rules reveals that outside of the realm of attorney ethics, no sanctions exist for clients and other individuals guilty of evidentiary spoliation.

\section{Perjury Statutes Almost Never Explicitly Apply to Arbitration}

The purpose of perjury laws is to encourage truth-telling in official matters by providing criminal consequences for lying under oath. ${ }^{38}$ One commentator noted: “"Perjury strikes at the very heart of our system . . . .

38. See In re Michael, 326 U.S. 224, 227 (1945) (noting that all "perjured relevant testimony is at war with justice, since it may produce a judgment not resting on truth. Therefore it cannot be denied that it tends to defeat the sole ultimate objective of a trial.”); United States v. Sainz, 772 F.2d 559, 562 (9th Cir. 1985) (describing the purpose of the perjury statutes as "truth-seeking”); Lisa Kern Griffin, Criminal Lying, Prosecutorial Power, and Social Meaning, 97 CALIF. L. REV. 1515, 1522 (2009) ("The perjury statute, which punishes knowingly making false, material statements under oath, protects the integrity of the court system.”); Linda F. Harrison, The Law of Lying: The Difficulty of Pursuing Perjury Under the Federal Perjury Statutes, 35 U. TOL. L. REV. 397, 399 (2003) (describing the legislative purposes behind perjury laws as based in encouraging truthful testimony). 
When people lie in court, it undermines the whole process. The problem is so bad that it is severely evaporating confidence people have in the court system.",39 The exact same concerns exist in arbitration. Adjudication based on false information undermines the systemwhether it occurs in the litigation system or the arbitral system.

As will be discussed in more detail, whether a person commits perjury by lying under oath in arbitration largely depends on whether arbitration is considered an "official proceeding" covered by the perjury statutes. The term "official proceeding" stems from the 1976 definition of perjury in the Model Penal Code (MPC), ${ }^{40}$ adopted by a majority of states. $^{41}$ Arbitration is simply not mentioned in the MPC chapter regarding perjury.

In contrast, the attorney ethics rules regarding truthfulness and suborning perjury turn on whether the false statements were made before a "tribunal." 42 In 2002, the American Bar Association added to its list of definitions the word "tribunal," which includes binding arbitration. ${ }^{43}$ Because of these more recent changes to the attorney ethics rules, there is a great disparity between traditional perjury ramifications for untruthfulness in arbitration and attorney obligations towards a tribunal, including an arbitral tribunal.

a. The Widely Used “Official Proceedings” Language Is Ambiguous in Its Applicability to Arbitration

Unsurprisingly, a large number of state legislatures enacted perjury laws in line with the MPC. Under the MPC, a person is guilty of perjury "if in any official proceeding, he makes a false statement under oath or

39. Mark Curriden, The Lies Have It, A.B.A. J. May 1995, at 69 (quoting former ABA Section of Litigation chair David Weiner); see also John L. Watts, To Tell The Truth: A Qui Tam Action for Perjury in a Civil Proceeding is Necessary to Protect the Integrity of the Civil Judicial System, 79 TEMP. L. REV. 773, 784 (2006) (“While this reluctance to criminally prosecute perjury in civil cases may be understandable, it is regrettable because perjury undermines the real and perceived legitimacy of the civil judicial system.”).

40. See Model Penal Code § 241.1(1) (Proposed Official Draft 1962) ("A person is guilty of perjury, a felony of the third degree, if in any official proceeding he makes a false statement under the oath or equivalent affirmation, or swears or affirms the truth of a statement previously made, when the statement is material and he does not believe it to be true." (emphasis added)).

41. See infra Part III.A.1.a.

42. See Model Rules of Prof’L CONDUCt R. 3.3(a)(1) (2002) (“A lawyer shall not knowingly[] make a false statement of fact or law to a tribunal.”).

43. Id. R. $1.0(\mathrm{~m})$ (“'Tribunal' denotes a court, an arbitrator in a binding arbitration proceeding or a legislative body, administrative agency or other body acting in an adjudicative capacity.”). 
equivalent affirmation, or swears or affirms the truth of a statement previously made, when the statement is material and he does not believe it to be true." ${ }^{44}$ The MPC defines "official proceeding" as "a proceeding heard or which may be heard before any legislative, judicial, administrative or other governmental agency or official authorized to take evidence under oath, including any referee, hearing examiner, commissioner, notary or other person taking testimony or deposition in connection with any such proceeding." 45 The terms "arbitration” and "arbitrator" are not found anywhere in this definition.

The following states adopted a perjury statute similar to the MPC that relies on the term "official proceeding": Alabama, ${ }^{46}$ Colorado, ${ }^{47}$ Connecticut, ${ }^{48}$ Florida, ${ }^{49}$ Hawaii, $^{50}$ Illinois, ${ }^{51}$ Kansas, ${ }^{52}$ Kentucky, ${ }^{53}$ Maine, ${ }^{54}$ Missouri, ${ }^{55}$ Montana, ${ }^{56}$ Nebraska, ${ }^{57}$ New Hampshire, ${ }^{58}$ New

44. Model Penal Code § 241.1(1) (Proposed Official Draft 1962).

45. Id. § 240.0(4).

46. ALA. CODE § 13A-10-101 (2010) (defining perjury as "in any Official proceeding”); id. $\S 13 A-10-100(\mathrm{~b})(5)$ (defining “official proceeding”).

47. Colo. Rev. Stat. ANN. § 18-8-502 (West 2004) (defining perjury as "in any official proceeding”); id. § 18-8-501(3) (defining “official proceeding”).

48. Conn. Gen. Stat. AnN. §53a-156 (West 2004) (defining perjury as "in any official proceeding”); id. § 53a-146(1) (defining “official proceeding”). Connecticut case law suggests that certain types of common law actions for perjury, including making false statements at arbitral, church, and grand jury proceedings are not covered under the MPC definition of "official proceeding." State v. Salafia, 284 A.2d 576, 578 (Conn. Super. Ct. 1971) ("The common-law definition of the crime was found to apply to testimony before arbitrators, before a church tribunal, before a grand jury, and in taking the poor debtor's oath before a justice of the peace." (citations omitted)). Other case law, however, describes arbitration as a "quasi-judicial" proceeding, opening the door for the perjury statute to apply to arbitrations. Preston v. O'Rourke, 811 A.2d 753, 760 (Conn. App. Ct. 2002) (“Oftentimes, '[a]rbitration is a quasi-judicial proceeding.” (quoting Florasynth, Inc. v. Pickholz, 750 F.2d 171, 171-74 (2d Cir. 1984))).

49. FLA. STAT. § 837.02 (2000) (defining perjury in an "official proceeding”); id. § 837.011(1) (defining "official proceeding”). Florida makes perjury not in an official proceeding a misdemeanor rather than a felony.

50. HAW. REV. STAT. §710-1060 (West 2008) (defining perjury as "in any official proceeding”); id. § 710-1000(12) (defining “official proceeding”).

51. 720 ILl. Comp. StAT. ANN. 5/32-2(a) (West 2010) (defining perjury as "in a proceeding or in any other matter where by law ... oath or affirmation is required").

52. Kan. Stat. ANN. § 21-5903(a)(1) (Supp. 2011) (defining perjury as a crime committed "before any court, tribunal, public body, notary public or other officer authorized to administer oaths").

53. Ky. Rev. Stat. ANN. §523.020 (West 2006) (defining perjury as "in any official proceeding”); id. § 523.010(3) (2010) (defining “official proceeding”).

54. ME. Rev. StAT. ANN. tit. 17-A § 451(1) (2006) (defining perjury as "[i]n any official proceeding”); id. §451(5)(A) (defining “official proceeding”). Maine also has a civil cause of action for perjury — the only state to have such a statute. ME. REv. STAT. ANN. tit. 14 § 870 (2003). The statute provides:

When a judgment has been obtained against a party by the perjury of a witness 
Mexico, ${ }^{59}$ North Dakota, ${ }^{60}$ Ohio, ${ }^{61}$ Pennsylvania, ${ }^{62}$ Utah, $^{63}$ and Washington. ${ }^{64}$ The applicability of these statutes to the arbitral forum is unclear. The definition of "official proceeding" leaves some room for interpretation, especially under the "other person taking testimony"

introduced at the trial by the adverse party, the injured party may, within 3 years after that judgment or after final disposition of any motion for relief from the judgment, bring an action against such adverse party, or any perjured witness or confederate in the perjury, to recover the damages sustained by the injured party by reason of such perjury. The judgment in the former action does not bar an action under this section.

Id. The applicability of this statute to arbitration is questionable. On the one hand, arbitration results in awards - not judgments. On the other hand, an award confirmed in court has the effect of a judgment. Id. $\S 5940$ ("Upon the granting of an order confirming, modifying or correcting an award, judgment or decree shall be entered in conformity therewith and be enforced as any other judgment or decree.”).

55. Mo. AnN. STAT. §575.040(1) (West 2011) (defining perjury as "in any official proceeding”); id. § 575.010(7) (defining “official proceeding”).

56. MONT. CODE ANN. § 45-7-201(1) (2011) (defining perjury as "in any official proceeding”).

57. NEB. REV. STAT. § 28-915(1) (2009) (defining perjury as "in any official proceeding”); id. $\S 28-916(3)$ (defining “official proceeding”).

58. N.H. REV. STAT. ANN. § 641:1(I) (2007) (defining perjury as "in any official proceeding”); id. § 641:1(II) (defining “official proceeding”).

59. N.M. StAT. AnN. §30-25-1(A) (West Supp. 2011) (defining perjury as in any "official proceeding”); id. § 30-1-12(G) (defining “official proceeding”).

60. N.D. Cent. Code AnN. § 12.1-11-01(1) (West Supp. 2011) (defining perjury as "in any official proceeding); id. § 12.1-01-04(22) (defining “official proceeding”).

61. OHIO REv. CoDE ANN. § 2921.11(A) (West 2006) (defining perjury as "in any official proceeding”); id. § 2921.01(D) (West Supp. 2011) (defining “official proceeding”).

62. 18 Pa. CONS. STAT. ANN. $\S 4902$ (West 1983) (defining perjury as "in any official proceeding”); id. § 4501 (defining “official proceeding”).

63. UTAH CODE ANN. §76-8-502 (West 2004) (defining perjury as "in any official proceeding”); id. § 76-8-501(1) (defining “official proceeding”).

64. WASH. ReV. CODE ANN. §9A.72.020 (West Supp. 2012) (defining perjury as "in any official proceeding”); id. § 9A.72.010(4) (2009) (defining “official proceeding”). The Washington perjury laws, like some other state laws, require that the oath taken be an oath mandated by law. See § 9A.72.020 (requiring false statement to be made "under an oath required or authorized by law"); see also id. § 9A.72.010(3) (“An oath is 'required or authorized by law' when the use of the oath is specifically provided for by statute or regulatory provision or when the oath is administered by a person authorized by state or federal law to administer oaths.”). As discussed in Part II, arbitration is generally a private dispute-resolution proceeding taking place outside of the court system. Accordingly no statutes "require" that an oath be administered within the arbitral forum. Certainly, many - if not most - arbitrators require that witnesses testify under oath, but such requirement is an arbitral requirement, not a statutory requirement. The American Arbitration Association Rules recognize that oaths are not necessarily required by law. Commercial Rule 25 provides: "Before proceeding with the first hearing, each arbitrator may take an oath of office and, if required by law, shall do so. The arbitrator may require witnesses to testify under oath administered by any duly qualified person and, if it is required by law or requested by any party, shall do so." AM. Arbitration Ass'N, Commercial Arbitration Rules R. 25 (2009); see also JAMS, JAMS Comprehensive ARbitration Rules \& Procedures R. 22(c) (2010) ("The Arbitrator shall require witnesses to testify under oath if requested by any party, or otherwise in the discretion of the Arbitrator."). 
portion of the definition. ${ }^{65}$ Does arbitration constitute a proceeding where testimony is being taken by the statutory "other person"?

Courts are split on whether arbitration falls under the MPC definition of "official proceeding." interpretation, then the MPC definition of "official proceeding" should not include an arbitral forum. To the extent that this ambiguous phrase at the end of the definition needs to be interpreted, it should be interpreted in line with the previously enumerated proceedings, i.e., judicial proceedings, legislative proceedings, administrative proceedings, depositions associated with the same, and the like. ${ }^{67}$ Additionally, the ambiguous phrase "any other person" is arguably limited by the phrase "governmental agency or official." 68 Contractual arbitrations, for the most part, take place outside of the realm of the government. Accordingly, the crime of perjury under the MPC likely does not extend to the arbitral forum.

65. Model Penal Code § 240.0(4) (Proposed Official Draft 1962).

66. For instance, numerous Florida cases granted arbitration witnesses immunity, noting the perjury consequences for falsely testifying under oath in arbitration. See Kidwell v. Gen. Motors Corp., 975 So. 2d 503, 505 (Fla. Dist. Ct. App. 2007) (applying witness immunity in part because "[a]n arbitration hearing, although informal, is a judicial or quasi-judicial proceeding”); Ruskin v. Ryan, 859 So. 2d 1218 (Fl. Dist. Ct. App. 2003) (affirming decision against former arbitration claimant based on perjury and other misconduct in arbitration); Turner v. Anderson, 704 So. 2d 748, 752 (Fla. Dist. Ct. App. 1998) (prohibiting a client from bringing a malpractice claim against former attorney when the client perjured himself on the advice of counsel). Illinois law, too, holds that witnesses in arbitration are immune from defamation lawsuits, noting in dicta that the perjury laws must apply to these witnesses. Bushell v. Caterpillar, Inc., 683 N.E.2d 1286, 1289 (Ill. App. Ct. 1997) ("Under Illinois law, absolute immunity applied to the arbitration hearing in this case. We wish to emphasize, however, that this does not mean that persons may lie to arbitrators with impunity. While absolute privilege provides complete immunity from civil action, it does not preclude criminal prosecution for perjury ....” (citations omitted)). In contrast, Nebraska perjury law only applies to a non-judicial "official proceeding" if the legislature requires that the procedure be given under oath. State v. Douglas, 388 N.W.2d 801, 807 (Neb. 1986). Unlike the Washington statute, see supra note 64, the Nebraska statute defining "official proceeding" is the exact same, facially broad definition found in the MPC. The Nebraska Supreme Court's judicial gloss on this definition is not necessarily dictated by the text of the statute.

67. This interpretation is in line with the statutory canon of ejusdem generis, which means that a court should interpret a generic term in line with more specific terms that precede the generic term.

68. See Model Penal CODE § 240.0(4) (emphasis added). This reading is generally in line with good grammar. The statutory language provides: "or other governmental agency or official authorized to take evidence under oath, including ... [a] notary or other person taking testimony ... in connection with any such proceeding." Id. Thus, the "other person" must be a governmental official. Also, the testimony must be before a judicial, legislative, or administrative agency. Arbitration is none of these and, thus, falls outside the MPC definition. 


\section{b. The Statutes Prohibiting Lying “Under Oath” Are Also Ambiguous}

Other states have adopted more generic perjury laws that simply prohibit lying under oath or making false sworn statements. ${ }^{69}$ If the statute prohibits lying under oath, and arbitral testimony is given under oath, then presumably these statutes would apply to arbitration. Courts, however, do not universally accept this interpretation.

States enacting these more generic perjury statutes include: Alaska, ${ }^{70}$ Arizona, ${ }^{71}$ Arkansas, ${ }^{72}$ California, ${ }^{73}$ Delaware, ${ }^{74}$ District of Columbia, ${ }^{75}$ Idaho $^{76}$ Indiana, ${ }^{77}$ Iowa, ${ }^{78}$ Maryland, ${ }^{79}$ Michigan, ${ }^{80}$ Minnesota, ${ }^{81}$

69. Many jurisdictions have a secondary offense of "false swearing." For states following the MPC, the false swearing statute covers lying under oath not in an official proceeding, as well as statements made in an official proceeding that fail the materiality prong of the test. MODEL PENAL CODE § 241.2 (proposed Official Draft 1962).

70. Alaska Stat. ANN. § 11.56.200 (West 2007) (defining perjury); id. § 11.56 .240 (defining "sworn statement”). Alaska's statute applies to arbitration proceedings. See Gilbert v. Sperbeck, 126 P.3d 1057, 1060 (Alaska 2005) (assuming, without deciding, that perjury rules apply to arbitration proceedings).

71. ARiz. Rev. Stat. ANN. § 13-2702 (2010) (defining perjury); id. § 13-2701 (defining "sworn statement”). Arizona courts, similarly, have applied perjury laws to arbitration—albeit attorney fee arbitration conducted by the judicial branch. See, e.g., State v. Self, 661 P.2d 224, 228 (Ariz. Ct. App. 1983) (holding that the "sworn statement" language in the perjury statute facially applies to arbitration, and finding that an arbitration hearing before the State Bar Committee constituted an "official proceeding" for the tampering charges).

72. ARK. CODE ANN. § 16-2-103 (West 2004) (defining perjury).

73. CAL. Penal Code $\S 118$ (West 1999) (defining perjury).

74. DEL. CODE ANN. tit. $11 \S 1221$ (West 2010) (defining perjury). Delaware, however, defines "testimony" as "an oral statement made under oath in a proceeding before any court, body, agency, public servant or other person authorized to conduct the proceeding and to administer the oath or cause it to be administered." Id. §1235(f). This definition of testimony is similar to the MPC definition of "official proceeding" and likely would be interpreted in a similar manner: excluding testimony before an arbitral body. See supra Part III.A.1.a.

75. D.C. CODE § 22-2402(a) (2001) (defining perjury). Although the D.C. courts have not ruled on whether arbitration counts as a "competent tribunal," they have ruled that a Congressional hearing so qualifies. See Young v. United States, 212 F.2d 236, 238-39 (D.C. Cir. 1954).

76. IDAHO CODE ANN. § 18-5401 (West 2006) (defining perjury).

77. IND. CODE ANN. § 35-44-2-1(a)(1) (West 2004) (“A person who: (1) makes a false, material statement under oath or affirmation, knowing the statement to be false or not believing it to be true ....”). This statute also criminalizes the making of two material, inconsistent statements where one is necessarily false, provided that the statements occur "in a proceeding before a court or grand jury.” Id. § 35-44-2-1(a)(2).

78. IOWA CODE ANN. § 720.2 (West 2003) (defining perjury). Iowa courts interpreted this statute as applying to mandatory arbitrations within the worker's compensation scheme. Cont'l Fire Sprinkler Co. v. Hoolandt, No. 01-0301, 2002 WL 700977, at *2 (Iowa Ct. App. Apr. 24, 2002).

79. Md. COdE ANN., CRIM. LAW § 9-101(a) (West 2002) (defining perjury).

80. Mich. COMP. LAWS ANN. § 750.423 (West 2004) (“Any person authorized by any statute of this state to take an oath, or any person of whom an oath shall be required by law, who shall willfully swear falsely, in regard to any matter or thing, respecting which such oath is authorized or required, 
Mississippi, ${ }^{82}$ New York, ${ }^{83}$ Oklahoma, ${ }^{84}$ Oregon, ${ }^{85}$ Rhode Island,${ }^{86}$ South Carolina, ${ }^{87}$ South Dakota, ${ }^{88}$ Tennessee; ${ }^{89}$ Texas, ${ }^{90}$ and Virginia. ${ }^{91}$ Although none of these statutes are identical, they all have a broad prohibition against lying under oath. The few cases interpreting these statutes generally hold that these statutes apply to arbitration proceedings or, more generally, to other situations in which a declarant testifies under oath but not at trial. ${ }^{92}$

shall be guilty of perjury, a felony ....”). In addition, Michigan has a separate statute for perjury in courts. Id. § 750.422 (making "[a]ny person who, being lawfully required to depose the truth in any proceeding in a court of justice guilty of perjury").

81. Minn. Stat. ANN. § 609.48(1) (West Supp. 2012).

82. MISS. CODE ANN. § 97-9-59 (West 2011). Mississippi courts apply this perjury statute to judicial proceedings other than civil and criminal trials. See, e.g., Smallwood v. State, 584 So. 2d 733, 739-42 (Miss. 1991) (discussing perjury charges based on a grand jury proceeding); Ford v. State, 956 So. 2d 301, 305-06 (Miss. Ct. App. 2006) (upholding a conviction for perjury based on a statement made at a probation revocation hearing).

83. N.Y. PeNal LAW § 210.15 (McKinney 2010) (defining perjury); id. § 210.00 (defining testimony). New York courts interpreted these statutes to apply to a hearing before the National Association of Securities Dealers (NASD), a body that widely uses arbitration to resolve disputes. People v. Cohen, 773 N.Y.S.2d 371, 385 (N.Y. App. Div. 2004).

84. OKLA. StAT. ANN. tit. 21, § 491 (West 2002) (defining perjury).

85. OR. REv. StAT. ANN. § 162.065(1) (West 2003) (defining perjury). In at least one case, the Supreme Court of Oregon applied the perjury statute to a statement outside of court-a statement in an application for a materialman's lien. State v. Carr, 877 P.2d 1192, 1193-94 (Or. 1994).

86. R.I. GEN. LAWS ANN. § 11-33-1(a) (West 2006) (defining perjury).

87. S.C. CODE ANN. § 16-9-30 (2003) (defining perjury). South Carolina, like Michigan, see supra note 80, also has a separate statute for perjury in judicial-and other-governmental proceedings. S.C. CODE ANN. § 16-9-10.

88. S.D. CODIFIED LAWS § 22-29-1 (2006) (defining perjury); see also State v. Brown, 480 N.W.2d 761, 761 (S.D. 1992) (affirming perjury conviction based on sworn testimony given to the South Dakota Board of Minerals and Environment).

89. TEnN. CoDE ANN. §39-16-702(a) (West 2011) (defining perjury). Tennessee courts interpret this statute broadly. See State v. Caraway, No. W2004-02948-CCA-R3-CO, 2005 WL 3287944, at *2 (Tenn. Crim. App. Dec. 2, 2005) (“As relevant here, a conviction for the offense of perjury merely requires proof that an accused made a false statement, under oath, with intent to deceive.”).

90. Tex. Penal Code AnN. § 37.02(a) (West 2011) (defining perjury). This statute applies to written statements under oath, even if the statements are not in the form of affidavits. See Martin v. State, 896 S.W.2d 336, 339 (Tex. Ct. App. 1995). Texas also has a separate statute for "aggravated perjury" if the perjury takes place in an "official proceeding." TEX. PENAL CODE ANN. § 37.03 (West 2011).

91. VA. CodE ANN. § 18.2-434 (West Supp. 2011) (defining perjury); see also id. § 18.2-435 (criminalizing conflicting testimony as perjury). Under Virginia law, any swearing under oath falls under the perjury statutes, not just swearing in judicial proceedings. Scott v. Commonwealth, 416 S.E.2d 47, 49 (Va. Ct. App. 1992) ("Neither Code § 18.2-434 nor Code § 18.2-435 expressly restricts 'testimony' to testimony given in judicial proceedings. In fact, Code $\S 18.2-434$ provides that it is perjury to swear falsely when an oath is lawfully administered 'on any occasion.'”).

92. See Gilbert v. Sperbeck, 126 P.3d 1057, 1060 (Alaska 2005) (assuming, without deciding, that the perjury rules apply equally to arbitration proceedings); State v. Self, 661 P.2d 224, 228-29 
Compared to the MPC definition of perjury, this broader definition more easily extends to arbitration. Because the statute does not limit perjury to "official proceedings," arbitration should fall squarely within the definition, even if not explicitly mentioned in the statute. This interpretation is far from assured given the ambiguities in the wording of the statutes. As will be discussed more fully, ${ }^{93}$ the clearest definition of perjury would explicitly reference arbitration; but for statutes that are deliberately vague, remaining vague will likely be the best statutory option.

c. A Minority of States Have Statutes Explicitly Applying toArbitration or Only to Judicial Proceedings

A small minority of states have more specific perjury statutes than the ones discussed previously. ${ }^{94}$ Only one state statute specifically references arbitration in its perjury statute, and the others only mention litigation-presumably to the exclusion of other instances in which a person makes a statement under oath.

Wisconsin is the only state that specifically mentions arbitration in its perjury statute. The arbitration provision, however, is quite limited in its scope. Under Wisconsin law, a person commits perjury if he makes a false material statement under oath, knowing the statement to be false, in a court, before a magistrate, before an agency, or before " $[\mathrm{a}] \mathrm{n}$ administrative agency or arbitrator authorized by statute to determine issues of fact." ${ }^{95}$ Again, because contractual arbitration falls outside of the legal system, this statute would not expressly extend to private, contractual arbitration. ${ }^{96}$ The specific inclusion of a hearing before an

(Ariz. Ct. App. 1983) (holding that the "sworn statement" language in the perjury statute facially applies to arbitration, and finding that an arbitration hearing before the State Bar Committee constituted an "official proceeding" for the tampering charges); Cont'l Fire Sprinkler Co. v. Hoolandt, No. 01-0301, 2002 WL 700977, at *2 (Iowa Ct. App. Apr. 24, 2002) (acknowledging perjury in a worker's compensation arbitration); Scott, 416 S.E.2d at 49 ("Neither Code $§ 18.2-434$ nor Code § 18.2-435 expressly restricts 'testimony' to testimony given in judicial proceedings. In fact, Code $\S 18.2-434$ provides that "it is perjury to swear falsely when an oath is lawfully administered 'on any occasion.'”).

93. See infra Part III.C.

94. See supra Parts III.A.1.a-b.

95. Wis. Stat. AnN. § 946.31(1) (West 2005) (emphasis added). The statute also lists other audiences for the perjury, including notary publics and officers conducting inquests of the dead. Id.

96. See Layton Sch. of Art \& Design v. Wis. Emp’t Relations Comm'n, 262 N.W.2d 218, 22829 (Wis. 1978) (holding that a labor arbitration fell within the perjury statute because the Wisconsin Employment Relations Commission was authorized by statute to select arbitrators). 
arbitrator "authorized by statute to determine issues of fact" likely means that any other arbitration would be interpreted as falling outside the scope of the statute. ${ }^{97}$ For being the state with the only mention of arbitration in the statute, the statute appears to have less effect than some more general perjury statutes. ${ }^{98}$

In contrast, New Jersey uses an MPC definition of perjury ${ }^{99}$ but defines "official proceeding" to include arbitration. Under New Jersey law, an "official proceeding" is a proceeding "heard or which may be heard before any legislative, judicial, administrative or other governmental agency, arbitration proceeding, or official authorized to take evidence under oath, including any arbitrator."100 Although this wording is somewhat ambiguous, the arbitration provision appears to be a "stand alone" consideration, and not tied to any official governmental proceedings. If interpreted in this manner, the New Jersey perjury law applies more clearly to arbitration than any other state's perjury law.

On the other side of specificity, some state perjury statutes are specifically limited to litigation procedures. For instance, perjury in Georgia is limited to statements made "in a judicial proceeding." 101 The Louisiana perjury law only applies in a "judicial proceeding" before a board "authorized to take testimony" or in legislative proceedings. ${ }^{102}$ The Massachusetts law applies solely in a "proceeding in a court of justice" ${ }^{\text {103 }}$ and does not extend to testimony at a labor arbitration. ${ }^{104}$ The

97. Under the canon of expressio unius, the inclusion of one thing suggests the exclusion of other things.

98. See supra Part III.A.1.b.

99. N.J. STAT. ANN. § 2C:28-1(a) (West 2005) (defining perjury in any official proceeding).

100. Id. § 2C:27-1(d).

101. GA. CODE ANN. § 16-10-70(a) (West 2003). Georgia courts apply this statute narrowly. See, e.g., Carter v. State, 516 S.E.2d 556, 562-63 (Ga. Ct. App. 1999) (holding that statements made in an application for a court-appointed attorney did not occur in a "judicial proceeding"). Georgia also has a more general "false swearing" statute that carries a lesser penalty than the perjury statute. GA. CODE ANN. §16-10-71(a) ("A person to whom a lawful oath or affirmation has been administered or who executes a document knowing that it purports to be an acknowledgment of a lawful oath or affirmation commits the offense of false swearing when, in any matter or thing other than a judicial proceeding, he knowingly and willfully makes a false statement.”).

102. LA. Rev. STAT. ANN. § 14:123(A) (2004 \& Supp. 2012).

103. MASS. GEN. LAWS ANN. ch. 268 § 1 (West 2012).

104. Ezekiel v. Jones Motor Co., 372 N.E.2d 1281, 1285 (Mass. 1978) ("While a witness at a judicial proceeding is free to make defamatory statements without fear of being sued by the defamed person, the witness is nevertheless subject to the control of the judge. If he or she gives false testimony, prosecution for perjury or punishment for contempt may be forthcoming. Such protections against false testimony, simply do not exist at a labor grievance hearing such as the one which took place here.”). The Ezekiel court recognized only a qualified immunity for grievance arbitration witnesses. Id. 
Nevada perjury law applies to statements made in a judicial proceeding or when otherwise required by law. ${ }^{105}$ The North Carolina law similarly provides that perjury occurs when the witness making false statements is "lawfully required to be sworn or affirmed."106 The Vermont perjury statute only applies "in a proceeding in a court of justice or in a contested case before a state agency."107 The West Virginia perjury law applies only at a "trial" or a "grand jury" in felony proceedings. ${ }^{108}$ The Wyoming perjury law applies to statements in "judicial, legislative or administrative proceedings." 109 These statutes are quite limited in their scope and likely do not apply to arbitral proceedings. Updated statutes would help keep these states in line with increased arbitration practice and the need for greater protections in arbitration.

Federal law also falls within this category of statutes. The general perjury statute applies to witnesses "having taken an oath before a competent tribunal, officer, or person, in any case in which a law of the United States authorizes an oath to be administered." ${ }^{110}$ Nothing in the FAA speaks to the ability to administer oaths, permissive or otherwise. ${ }^{111}$ Without a direct mention of an oath within the statute, arbitrations cannot be tribunals "in which a law of the United States authorizes an oath to be administered.” Thus, federal law provides no support for a truth-telling

105. NEV. ReV. Stat. ANN. § 199.120 (West 2011). Nevada case law emphasizes that an oath must be required by law-i.e., not voluntary-before the statute applies. Licata v. State, 661 P.2d 1306, 1307 (Nev. 1983) ("We construe the language of the statute to mean that a perjury charge may be sustained only where the false statement was made in a judicial or other setting where an oath or affirmation is legally required. Appellant's voluntary statement taken in the insurance company lawyer's office does not fall within the purview of the statute and thus, appellant could not have been found guilty of perjury in this case.”).

106. N.C. GEN. STAT. ANN. § 14-209 (West 2011). Interestingly, despite the limited nature of the perjury statute, the North Carolina Supreme Court also held that a witness is immune from civil liability based on testimony given in an arbitration proceeding. See Brewer v. Carolina Coach Co., 116 S.E.2d 725, 728 (N.C. 1960) (affirming dismissal of civil suit for damages resulting from allegedly perjured testimony in an arbitration on the basis of witness immunity). This article addresses witness immunity. See infra Part III.C.4.

107. 13 VT. STAT. ANN. § 2901 (West 2011).

108. W. VA. CODE ANN. § 61-5-1(a) (West 2012). Even West Virginia’s statute for felony false swearing is limited to "trials." Id. § 61-5-2. Case law interprets these statutes very narrowly. See Farber v. Douglas, 361 S.E.2d 456, 463 (W.Va. 1985) ("In order to support a charge of false swearing ... the person administering the oath or affirmation must be qualified to do so and the sworn testimony, document, or affidavit must be authorized by law to be rendered under an oath or affirmation.”); State v. Schoonover, 124 S.E.2d 340, 345 (W. Va. 1962) (“Obviously, if the Crime Commission of West Virginia was not constitutionally created, the defendant could not be convicted of false swearing as to testimony purportedly given before it.”).

109. WyO. STAT. ANN. § 6-5-301(a) (West 2011).

110. 18 U.S.C. $\S 1621(1)$ (2006).

111. See 9 U.S.C. § 1-16 (2006). 
requirement in arbitration, and this law, too, will need a revision to apply to the arbitral forum.

\section{Attorney Ethics Rules on Truthfulness Generally Apply to Arbitration}

While perjury statutes provide criminal consequences to witnesses who lie under oath, attorneys have additional obligations to be truthful toward a tribunal. All attorneys are bound by ethical rules that govern their behavior, and each state promulgates its own ethical rules. ${ }^{112}$ Most states' ethical rules model the version of the Model Rules of Professional Conduct (the Model Rules) published in 2002. ${ }^{113}$ Unlike the MPC, the Model Rules of Professional Conduct explicitly apply to arbitration proceedings and other alternative dispute resolution processes. ${ }^{114}$

The "Ethics 2000" revisions, changes made to the Model Rules by the ABA's Commission on Evaluation of the Rules of Professional Conduct, contained a number of revisions to the ethical rules specifically targeted at alternative dispute resolution. ${ }^{115}$ Included in these revisions were rules for the attorney/advocate within ADR procedures, including arbitration. ${ }^{116}$ One of the ways that the Ethics 2000 Commission included arbitration practice within the parameters of the general rules

112. See Susan Poser, Multijurisdictional Practice for a Multijurisdictional Profession, 81 NEB. L. REV. 1379, 1382 (2003) ("Historically, the state supreme courts have regulated the lawyers in their states.” (footnote omitted)). Although the American Bar Association publishes a set of model rules of professional conduct, each state is free to adopt its own rules. There exists no national bar association for attorneys and, therefore, no nationally applicable ethical rules for attorneys.

113. See Chronological List of States Adopting Model Rules, ABA, http://www.americanbar.org/ groups/professional_responsibility/publications/model_rules_of_professional_conduct/chrono_list_s tate_adopting_model_rules.html (last visited Apr. 7, 2012). California is the only state that does not have rules following the Model Rules; only five states have not yet adopted the 2000 revisions. Id.

114. Model Rules of PROF'L ConduCt R. 2.4 cmt. 5 (2002).

115. See Douglas H. Yarn, Lawyer Ethics in ADR and the Recommendations of Ethics 2000 to Revise the Model Rules of Professional Conduct: Considerations for Adoption and State Application, 54 ARK. L. REV. 207, 207, 212-13 (2001) (“[T]here was little consideration of ethical issues affecting lawyers in ADR when the Kutak Commission drafted the Model Rules [adopted by the ABA in 1983] . . . . Ethics 2000 provided a unique opportunity to incorporate these ADR-related principles into the Model Rules.”). The changes considered both attorneys as advocates as well as attorneys serving as third-party neutrals within an ADR forum. Carrie Menkel-Meadow, The Lawyer as Consensus Builder: Ethics for a New Practice, 70 TenN. L. ReV. 63, 85 (2002) (describing the need for the Ethics 2000 Commission to create rules for attorneys as third-party neutrals). One of the overarching goals of the Ethics 2000 Commission was to update the rules to adapt "to the realities of modern law practice and the limits of professional discipline." MODEL RULES OF PROF’L CONDUCT, Preface (2002).

116. Yarn, supra note 115, at 245 (noting that the crafting of these rules was difficult given the "competing philosophies, paradigms, or visions of what an ADR attorney's behavior should be”). 
was to define a previously undefined term: "tribunal." Under the revisions, a tribunal includes "a court, an arbitrator in a binding arbitration proceeding or a legislative body, administrative agency or other body acting in an adjudicative capacity." explanation for the new definition of tribunal is the following: "This term was not previously defined. The Commission recommends including a definition and including not only courts but also binding arbitration and legislative bodies, administrative agencies or other bodies acting in an adjudicative capacity."118 For the states adopting this definition, any portion of the ethical rules referencing a tribunal now applies to arbitration-or at least binding arbitration. For the states that have not adopted this definition, whether the ethics rules referencing tribunalincluding the truthfulness rules - apply to arbitration at all is unclear. ${ }^{119}$

The Ethics 2000 Commission used the new definition to delineate the types of behavior appropriate before a tribunal. ${ }^{120}$ One of the key issues before the Commission was the issue of truthfulness toward a tribunal. $^{121}$ The final text of Rule 3.3, dealing with "Candor Toward the Tribunal," reads:

(a) A lawyer shall not knowingly:

117. Model Rules of Prof’L Conduct R. 1.0(m) (2002) (emphasis added). “Tribunal” also includes courts, legislative bodies, agencies, and any "other body acting in an adjudicative capacity." Yarn notes that one of the reasons why arbitration was included within the definition of the word tribunal is because "[a]lthough arbitral bodies are often referred to as 'tribunals' and are adjudicative in nature, their inclusion [was] uncertain.” Yarn, supra note 115, at 255. One criticism of this change is the fact that only binding and adjudicative forums fall within this rule. The rule does not extend to the mediation forum or other non-binding forms of ADR. See Menkel-Meadow, supra note 115, at 95 ("In mediations and non-binding arbitrations there are no obligations to volunteer information or to correct misinformation by other parties or lawyers in the proceedings unless the duty is imposed by other law, such as state fraud law or rules of civil procedure.").

118. Model Rule 1.0: Reporter's Explanation of Changes, ABA, http://www.americanbar.org/ groups/professional_responsibility/policy/ethics_2000_commission/e2k_rule10rem.html (last visited Apr. 7, 2012).

119. Charts Comparing Professional Conduct Rules, ABA, http://www.americabar.org/groups/ professional_responsibility/policy/charts.html (last visited Apr. 7, 2012).

120. Douglas R. Richmond, The Ethics of Zealous Advocacy: Civility, Candor and Parlor Tricks, 34 TEX. TECH. L. REv. 3, 6 (2002) (“Overzealous lawyers may not honor their duty of candor to tribunals before which they appear. This sometimes takes the form of a lawyer's failure to disclose controlling legal authority directly adverse to his client's position. A lawyer may make a false statement of material fact or law to a tribunal, or offer evidence that the lawyer knows to be misleading or false.”).

121. See David W. Raack, The Ethics 2000 Commission's Proposed Revision of the Model Rules: Substantive Change or Just a Makeover?, 27 OHIO N.U. L. REV. 233, 253 (2001) (“A perennial issue in legal ethics concerns a lawyer's responsibilities to a court or tribunal when the lawyer learns of client perjury or fraud on the tribunal.”). 
(1) make a false statement of fact or law to a tribunal or fail to correct a false statement of material fact or law previously made to the tribunal by the lawyer;

(2) fail to disclose to the tribunal legal authority in the controlling jurisdiction known to the lawyer to be directly adverse to the position of the client and not disclosed by opposing counsel; or

(3) offer evidence that the lawyer knows to be false. If a lawyer, the lawyer's client, or a witness called by the lawyer, has offered material evidence and the lawyer comes to know of its falsity, the lawyer shall take reasonable remedial measures, including, if necessary, disclosure to the tribunal. A lawyer may refuse to offer evidence, other than the testimony of a defendant in a criminal matter, that the lawyer reasonably believes is false.

(b) A lawyer who represents a client in an adjudicative proceeding and who knows that a person intends to engage, is engaging or has engaged in criminal or fraudulent conduct related to the proceeding shall take reasonable remedial measures, including, if necessary, disclosure to the tribunal. ${ }^{122}$

Thus, under Rule 3.3, in conjunction with the new definition of tribunal, a lawyer is prohibited from making false statements and from knowingly entering the false statements of others into evidence before an arbitral tribunal. The states that have not yet adopted this definition of tribunal should do so in order to clear up any ambiguities about the application of these ethical rules. ${ }^{123}$

\section{B. Although Document Tampering Laws Do Not Apply to Arbitral Proceedings, Common Law Claims and Presumptions Do Apply, in Addition to Attorney Ethics Rules}

This section considers the laws regarding tampering and destruction-also called spoliation-of physical and documentary evidence. The first subsection considers the criminal laws for tampering, which-like the perjury laws - generally do not apply to arbitration. The second section considers common law causes of action for tampering and spoliation, and how those rules apply to arbitration. The third section considers how arbitrators apply spoliation rules within their hearings

122. Model Rules of Prof’L CONDUCT R. 3.3(a), (b) (2002) (emphasis added).

123. One criticism of dealing with the problem of lying in arbitration through the ethical rules is the fact that attorney discipline alone may be an unsatisfying remedy for a wronged arbitration party. 
(and they are!). Finally, this section considers how attorney ethics rules prevent this type of behavior from occurring in the arbitral forum.

\section{Criminal Tampering Laws, Like Perjury Laws, Largely Do Not Apply to Arbitration}

Evidence before an arbitral tribunal, like at trial, includes both testimonial evidence and documentary evidence. While the perjury laws apply to testimonial evidence, they do not extend to physical evidence or documents. Physical evidence and document tampering statutes criminalize the destruction, alteration, and concealment of documents or other physical evidence that could be used in an action, such as a trial. ${ }^{124}$ Just as with the perjury laws, ${ }^{125}$ the MPC has a model statute that many states have adopted. MPC section 241.7 provides:

A person commits a misdemeanor if, believing that an official proceeding or investigation is pending or about to be instituted, he:

(a) alters, destroys, conceals or removes any record, document or thing with purpose to impair its verity or availability in such proceeding or investigation; or

(b) makes, presents or uses any record, document or thing knowing it to be false and with purpose to mislead a public servant who is or may be engaged in such proceeding or investigation. ${ }^{126}$

Again, just like with the perjury statutes, the tampering statute references an "official proceeding." 127 The same definition of "official proceeding" that applies to perjury laws and nowhere mentions arbitration, seemingly excluding the process, also applies to tampering laws. ${ }^{128}$

The following states have a similar tampering statute that references “official proceedings": Alabama, ${ }^{129}$ Alaska, ${ }^{130}$ Arizona,${ }^{131}$ Arkansas, ${ }^{132}$

\footnotetext{
124. See, e.g., Model PenAl CodE § 241.7 (Proposed Official Draft 1962) (criminalizing tampering with physical evidence if believing "an official proceeding or investigation is pending or about to be instituted").

125. See supra Part III.A.1.

126. Model Penal Code § 241.7; see, e.g., 720 ILl. Comp. Stat. AnN. 5/31-4 (West 2010); OHIO REV. CODE ANN. § 2921.32 (West 2006).

127. Model Penal Code $§ 241.7$.

128. Model PenAl Code $§$ 240.0(4) (Official Proposed Draft 1962); see supra Part III.A.1.a.

129. AlA. CODE § 13A-10-129 (2006).

130. ALASKa StAT. ANN. § 11.56 .610 (West 2007).
} 

Colorado, ${ }^{133}$ Connecticut, ${ }^{134}$ Delaware, ${ }^{135}$ the District of Columbia, ${ }^{136}$
Hawaii, ${ }^{137}$ Idaho, ${ }^{138}$ Kentucky, ${ }^{139}$ Michigan, ${ }^{140}$ Mississippi, ${ }^{141}$
Montana, ${ }^{142}$ Nebraska, ${ }^{143}$ New Hampshire, ${ }^{144}$ New Jersey, ${ }^{145}$ New
York, ${ }^{146}$ North Dakota, ${ }^{147}$ Ohio, ${ }^{148}$ Oklahoma, ${ }^{149}$ Oregon, ${ }^{150}$
Pennsylvania, ${ }^{151}$ South Dakota, ${ }^{152}$ Tennessee, ${ }^{153}$ Texas, ${ }^{154}$ Utah, ${ }^{155}$ and
Washington. ${ }^{156}$ Considerably more uniformity exists among the states as
to document tampering statutes than as to perjury statutes. ${ }^{157}$
Unfortunately, the effect of this uniformity is that these tampering laws

\footnotetext{
131. ARIZ. REV. STAT. ANN. § 13-2809 (2006).

132. ARK. CODE ANN. § 5-53-111 (West 2008).

133. Colo. Rev. Stat. AnN. § 18-8-610 (West 2004).

134. Conn. Gen. StAT. ANN. § 53a-155 (West 2007).

135. DeL. CoDE ANN. tit. 11, § 1269 (West 2010).

136. D.C. CODE. § 22-723 (Supp. 2011).

137. HAW. REV. STAT. § 710-1076 (West 2008).

138. IDAHO CODE ANN. § 18-2603 (West 2006) (referencing "any ... proceeding ... authorized by law").

139. Ky. ReV. Stat. AnN. § 524.100 (West 2006).

140. Mich. Comp. LAWS ANN. § 750.483a(5) (West 2004).

141. Miss. CODE ANN. § 97-9-125 (West 2011).

142. Mont. Code AnN. § 45-7-207 (2011).

143. NEB. REV. STAT. § 28-922 (2009).

144. N.H. REV. STAT. ANN. § 641:6 (2007).

145. N.J. STAT. ANN. § 2C:28-6 (West 2005).

146. N.Y. PENAL LAW § 215.40 (McKinney 2010).

147. N.D. CENT. CODE ANN. § 12.1-09-03 (West 2008). Interestingly, the North Dakota statute also applies when an individual believes "process, demand, or order has been issued or is about to be issued." Id. The definition of "process, demand, or order" potentially applies to arbitration. The terms mean "process, demand, or order authorized by law for the seizure, production, copying, discovery, or examination of a record, document, or thing." Id.

148. OHIO REv. Code ANN. § 2921.12 (West 2006).

149. OKLA. STAT. ANN. tit. 21, § 454 (West 2002) (covering tampering where an individual knows evidence is about to be produced in any "proceeding . . . authorized by law").

150. OR. ReV. STAT. ANN. § 162.295 (West 2003).

151. 18 Pa. Cons. STAT. ANN. $\S 4910$ (West 1983).

152. S.D. CODIFIED LAWS § 19-7-14 (2004). South Dakota only uses the term "proceeding” and not "official proceeding," which might more easily extend to arbitration.

153. TenN. CodE ANN. § 39-16-503 (West 2011).

154. TeX. Penal Code AnN. § 37.09 (West 2011).

155. UTAH CODE ANN. § 76-8-510.5 (West 2004). In this statute, Utah defines the term "official proceeding" to include any "civil or administrative action, trial, examination under oath, administrative proceeding, or other civil or administrative adjudicative process." Id. This definition of "official proceeding" is broader than the definition found in the MPC and could arguably include arbitration under the "examination under oath" catch-all.

156. WASH. REV. CODE ANN. § 9A.72.150 (West 2009).

157. See supra Part III.A.1.
} 
do not apply to the arbitral forum given the limiting definition of the key term "official proceeding."

The benefit of this uniformity is the relative ease of a uniform change to extend tampering laws to the arbitral forum. Revising the MPC definition of "official proceeding" to include arbitration would make the MPC tampering law equally applicable to arbitration as to the litigation forum. After revising the MPC, the states could consider the revisions and make the appropriate changes to their own criminal law. For reasons discussed in subsequent sections, every state should update its law to include arbitration within the ambit of these criminal laws.

\section{It Is an Open Question Whether a Common Law Cause of Action for Spoliation Applies to Arbitration}

Some states recognize a common law cause of action in tort for damages suffered by virtue of one party's document destruction. ${ }^{158} \mathrm{~A}$ minority of jurisdictions allow the party who should have received certain discovery to bring a cause of action against the party who negligently or intentionally destroyed the evidence. ${ }^{159}$ This cause of action can be maintained either as a separate lawsuit or as a claim within the underlying litigation. ${ }^{160}$

158. Cecelia Hallinan, Comment, Balancing the Scales After Evidence Is Spoiled: Does Pennsylvania's Approach Sufficiently Protect the Injured Party?, 44 VILL. L. REV. 947, 956 (1999) ("A minority of states have determined that traditional remedies are inadequate because although they serve a punitive function, they do not fully compensate the spoliation victim. Furthermore, traditional remedies fail to address the situation where a third party uninvolved in the litigation destroys the evidence. Consequently, these states have recognized a new tort cause of action that allows the injured party to bring an action against the spoliator for damages caused by evidence destruction.”).

159. Id.

160. Id. at 958. Some jurisdictions require that the underlying lawsuit be complete before bringing a cause of action for spoliation of evidence. Id. For states employing this type of timing, the reason is likely because the cause of action would not accrue without knowing the outcome of the underlying action. In other words, a plaintiff cannot prove the harm without first losing the underlying case. 
The states of Alaska, ${ }^{161}$ Kansas, ${ }^{162}$ Ohio, ${ }^{163}$ Illinois, ${ }^{164}$ Indiana, ${ }^{165}$ Louisiana, ${ }^{166}$ Montana, ${ }^{167}$ New Mexico, ${ }^{168}$ West Virginia, ${ }^{169}$ and New Jersey ${ }^{170}$ recognize the tort, as does the District of Columbia. ${ }^{171}$ A plaintiff in these states establishes the tort by showing: (1) the existence of a potential civil action; (2) defendant's knowledge of the potential action; (3) destruction of evidence; (4) intent; (5) inability to prove the original claim, i.e., proximate cause; and (6) damages. ${ }^{172}$ A limited number of jurisdictions recognize a tort for both intentional and negligent spoliation of evidence. ${ }^{173}$ Negligent spoliation of evidence involves the same test, substituting the requirement of "intent" with the requirement of a duty between the parties to preserve the evidence. ${ }^{174}$

Whether this common law cause of action applies to arbitration turns on the definition of a "civil action." The courts have yet to decide this issue. ${ }^{175}$ Perhaps parties within arbitration could argue that a civil action

161. Nichols v. State Farm Fire \& Cas. Co., 6 P.3d 300, 303 (Alaska 2000) (recognizing tort of intentional spoliation of evidence).

162. Foster v. Lawrence Mem'l Hosp., 809 F. Supp. 831, 838 (D. Kan. 1992).

163. Smith v. Howard Johnson Co., 615 N.E.2d 1037, 1038 (Ohio 1993).

164. Dardeen v. Kuehling, 821 N.E.2d 227, 336 (Ill. 2004) (establishing the tort of negligent spoliation of evidence as a cause of action).

165. Glotzbach v. Froman, 827 N.E.2d 105, 108 (Ind. Ct. App. 2005) (establishing a cause of action for both intentional and negligent spoliation, but only if a duty exists between the parties), vacated, 854 N.E.2d 337 (Ind. 2006).

166. Desselle v. Jefferson Parish Hosp. Dist. No. 2, 887 So. 2d 524, 534 (La. Ct. App. 2004) (recognizing a tort of intentional spoliation).

167. Gentry v. Douglas Hereford Ranch, Inc., 962 P.2d 1205 (Mont. 1998).

168. Coleman v. Eddy Potash, Inc., 905 P.2d 185, 190 (N.M. 1995) (recognizing intentional spoliation of evidence as a cause of action), rev'd on other grounds, 34 P.3d 1148 (N.M. 2001).

169. Hannah v. Heeter, 584 S.E.2d 560, 569-70 (W. Va. 2003).

170. Manorcare Health Servs., Inc. v. Osmose Wood Preserving, Inc., 764 A.2d 475, 482 (N.J. Super. Ct. App. Div. 2001) (noting that destruction of evidence could result in a separate tort for spoliation, discovery sanctions, or an adverse inference jurisdiction).

171. See Hallinan, supra note 158, at 958; see also Holmes v. Amerex Rent-A-Car, 710 A.2d 846, 854 (D.C. 1998); Yoakum v. Hartford Fire Ins. Co., 923 P.2d 416, 422-23 (Idaho 1996) (holding that even if Idaho did recognize the tort, the plaintiffs had not proven the elements).

172. Hallinan, supra note 158, at 958; see also supra notes 161-71.

173. Id.

174. Smith v. Howard Johnson Co. Inc., 615 N.E.2d 1037, 1038 (Ohio 1993) (recognizing the tort of negligent spoliation, provided that the parties have a special relationship).

175. Some courts require the arbitration of spoliation claims if such claims fall within the arbitration agreement between the parties. See, e.g., Clyde Bergemann, Inc. v. Sullivan, Higgins \& Brion, PPE LLC, No. 08-162-KI2008 WL 2116908, at*3 (D. Or. May 14, 2008) (compelling a case to arbitration and requiring the arbitrator to deal with potential spoliation claim); Positive Software Solutions Inc. v. New Century Mortg. Corp., 259 F. Supp. 2d 561, 562 (N.D. Tex. 2003) (sending the spoliation claim to arbitration, confident that the arbitrator would take the claim very seriously); Dantz v. Apple Ohio LLC, 277 F. Supp. 2d 794, 805 (N.D. Ohio 2003) (compelling a case to 
extends to arbitration. Some evidence exists that arbitrators have been asked for an award based on spoliation of evidence. ${ }^{176}$ Until arbitrators begin to award damages for spoliation of evidence and those awards are challenged in court, this question remains open.

\section{An Arbitrator May Apply Burden-Shifting Penalties and Sanctions in the Arbitral Forum}

In addition to the possible criminal liability for destroying documents and civil liability in a cause of action for spoliation, ${ }^{177}$ if a litigant alleges spoliation in the original case, then that party may be eligible to receive a burden-shifting inference in that party's favor. The victim of spoliation may also be eligible to receive sanctions from the offending party in the form of attorney's fees or other monetary sanctions. Nearly every state in the United States allows for some form of sanctions against the spoliating party in a civil case. ${ }^{178}$

arbitration that included a potential claim for spoliation).

176. Some arbitral opinions evince that parties have asked for damages for a cause of action for spoliation. For instance, a pair of cases before the National Association of Securities Dealers involved denied claims for spoliation of evidence based on the merits of the claim, rather than the inability of the claimants to recover under the cause of action. See Parsons v. Prudential Ins. Co. of Am., No. 98-01744, 1999 WL 681721, at *2 (N.A.S.D. July 8, 1999) (describing claimants' requesting damages for lost income, compensatory damages, exemplary damages, attorney's fees, pre-judgment interest, and further relief the panel deems proper); Rose v. Lehwald Orosey Pepe, Inc., No. 96-02274, 1998 WL 1178726, at *2 (N.A.S.D. Aug. 5, 1998) (describing claimants' requesting a reward against respondents for reinstatement, back-pay interest, front pay, compensatory and punitive damages, costs, attorney's fees, accounting fees, expert witness fees, and other relief the panel deems proper).

177. See supra Parts III.B.1-2.

178. See, e.g., Smith v. Atkinson, 771 So. 2d 429, 438 (Ala. 2000) (awarding an adverse inference and monetary sanctions); Souza v. Fred Carries Contracts, Inc. 955 P.2d 3, 6 (Ariz. Ct. App. 1997) (recognizing availability of varying sanctions depending on the severity of the spoliation); Tomlin v. Wal-Mart Stores, Inc., 100 S.W.3d 57, 62-63 (Ark. Ct. App. 2003) (adverse inference); Cedars Sinai Med. Ctr. v. Superior Court, 954 P.2d 511, 517 (Cal. 1998) (adverse inference, sanctions, disciplinary action, or criminal action); Pfantz v. Kmart Corp., 85 P.3d 564, 569 (Colo. App., 2003) (adverse inference); Beers v. Bayliner Marine Corp., 675 A.2d 829, 832-33 (Conn. 1996) (adverse inference); Lucas v. Christiana Skating Ctr., Ltd., 722 A.2d 1247, 1250 (Del. Super. Ct. 1998) (adverse inference); Public Health Trust of Dade Cnty. v. Valcin, 507 So. 2d 596, 599 (Fla. 1987) (burden shifting); Chapman v. Auto Owners Ins. Co., 469 S.E.2d 783, 786 (Ga. Ct. App. 1996) (adverse inference, dismissal, or exclusion of evidence); Courtney v. Big O Tires, Inc., 87 P.3d 930, 933 (Idaho 2003) (adverse inference); Lynch v. Saddler, 656 N.W.2d 104, 111 (Iowa 2003) (adverse inference); Monsanto Co. v. Reed, 950 S.W.2d 811, 815 (Ky. 1997) (adverse inference, monetary sanctions); Guillory v. Dillard’s Dept. Store, Inc., 777 So. 2d 1, 3 (La. Ct. App. 2000) (adverse inference); Driggin v. Am. Sec. Alarm Co., 141 F. Supp. 2d 113, 120 (D. Me. 2000) (adverse inference, dismissal, monetary sanctions); Anderson v. Litzenberg, 694 A.2d 150, 155 (Md. Ct. Spec. App., 1997) (adverse inference); Gath v. M/A-Com, Inc., 802 N.E.2d 521, 534 (Mass. 2003) (adverse inference, exclusion of evidence, dismissal); Trupiano v. Cully, 84 N.W.2d 747, 748 
Unlike the tort of spoliation of evidence, some anecdotal evidence suggests that arbitrators are, in fact, granting this burden-shifting inference and sanctions in the arbitral forum. For example, in Jones $v$. PPG Industries, Inc. the Third Circuit Court of Appeals affirmed the confirmation of an arbitral award in which the arbitrator found for a defendant company despite employing an inference against the defendant because of missing file documents. ${ }^{179}$ In Jones, the plaintiff-employee in a discrimination case argued that the lack of production of e-mail and other communications meant that such communications and documents had been destroyed. ${ }^{180}$ The arbitrator largely disagreed ${ }^{181}$ but found that an investigatory file did exist and was missing at the time of arbitration. ${ }^{182}$ The arbitrator applied an adverse inference with respect to this missing file but still found for the defendant. ${ }^{183}$ The arbitrator concluded that, even with the inference, "given the record evidence adduced at the hearing, [the plaintiff] had not demonstrated unlawful

(Mich. 1957) (adverse inference); Patton v. Newmar Corp., 538 N.W.2d 116, 119 (Minn. 1995) (adverse inference); Tolbert v. State, 511 So. 2d 1368, 1372-73 (Miss. 1987) (adverse inference); Baldrige v. Dir. of Revenue, 82 S.W.3d 212, 222-23 (Mo. Ct. App. 2002) (adverse inference); State v. Davlin, 639 N.W.2d 631, 648 (Neb. 2002) (adverse inference); Reingold v. Wet 'N Wild Nev., Inc., 944 P.2d 800, 802 (Nev. 1997) (adverse inference), overruled by Bass-Davos v. Davis, 134 P.3d 103, 109 (Nev. 2006); Rodriguez v. Webb, 680 A.2d 604, 606-07 (N.H. 1996) (adverse inference); Swick v. N.Y. Times Co., 815 A.2d 508, 511 (N.J. Super. Ct. App. Div. 2003) (adverse inference, monetary sanctions); Segura v. K-Mart Corp., 62 P.3d 283, 286-87 (N.M. Ct. App. 2002) (adverse inference, dismissal); Amaris v. Sharp Elecs., 758 N.Y.S.2d 637, 638 (N.Y. App. Div. 2003) (dismissal or lesser sanction); McLain v. Taco Bell Corp., 527 S.E.2d 712, 715 (N.C. Ct. App. 2000) (adverse inference); Bachmeier v. Wallwork Truck Ctrs., 544 N.W.2d 122, 124 (N.D. 1996) (dismissal, preclusion of evidence, adverse inference); Barker v. Wal-Mart Stores, Inc., No. 01AP658, 2001 WL 1661961, at *7 (Ohio Ct. App. Dec. 31, 2001) (adverse inference, discovery sanctions); Manpower, Inc. v. Brawdy, 62 P.3d 391, 392 (Okla. Civ. App. 2002) (adverse inference); Mead v. Papa Razzi Rest., 840 A.2d 1103, 1108 (R.I. 2004) (adverse inference); Wis. Motor Corp. v. Green, 79 S.E.2d 718, 720-21 (S.C. 1954) (adverse inference); Cody v. Leapley, 476 N.W.2d 257, 264 (S.D. 1991) (adverse inference); Foley v. St. Thomas Hosp., 906 S.W.2d 448, 453-54 (Tenn. Ct. App. 1995) (adverse inference); Trevino v. Ortega, 969 S.W.2d 950, 953 (Tex. 1998) (adverse inference); Lavalette v. Noyes, 205 A.2d 413, 415 (Vt. 1964) (“presumption of falsity”); Jacobs v. Jacobs, 237 S.E.2d 124, 127 (Va. 1977) (adverse inference); Pier 67, Inc. v. King Cnty., 573 P.2d 2, 6 (Wash. 1977) (adverse inference); Hannah v. Heeter, 584 S.E.2d 560, 566-68 (W. Va. 2003) (sanctions, adverse inference, tort claim in some circumstances); Jagmin v. Simonds Abrasive Co., 211 N.W.2d 810, 821 (Wis. 1973) (adverse inference, sanctions); Abraham v. Great W. Energy, LLC, 101 P.3d 446, 455 (Wyo. 2004) (adverse inference).

179. 393 F. App’x 869, 870-71 (3d Cir. 2010).

180. Id. at 870 . The plaintiff, however, could not demonstrate that the e-mail messages ever existed and only surmised that such messages should have existed and that their absence indicated that the corporation deliberately destroyed evidence helpful to his case. Id.

181. Id. at 871 .

182. Id. at $870-71$.

183. Id. 
discrimination or retaliation." 184 The plaintiff then moved to vacate under manifest disregard. ${ }^{185}$ The district court denied the plaintiff's motion and the Third Circuit affirmed. ${ }^{186}$ Given the scope of the arbitral hearing and the well-reasoned opinion, the Third Circuit affirmed the finding that the arbitrator did not exceed his powers. ${ }^{187}$

In some cases, the arbitrator uses the evidence of spoliation to figure a damages award. For instance, in Davis v. Reliance Electric Industrial Co., a Tennessee court confirmed an award of compensatory and punitive damages to a former employee in a retaliatory discharge case involving lost or destroyed critical documentary evidence. ${ }^{188}$ The plaintiff incurred two work-related injuries, and his employer fired him for excessive absenteeism. ${ }^{189}$ The plaintiff alleged he was fired for seeking workers compensation benefits. ${ }^{190}$ During the course of the case, the employer-defendant failed to produce an important performance evaluation and attendance record. ${ }^{191}$ The arbitrator was troubled by the missing documents, stating that "it was 'beyond belief' that the documents could be 'missing' when they were absolutely crucial to the defense." 192 Ultimately, the arbitrator awarded compensatory damages, emotional distress damages, and punitive damages of $\$ 525,000$ based on the defendant's net worth. ${ }^{193}$ The arbitrator awarded the punitive damages, in part, because of the defendant's destruction of evidence. ${ }^{194}$ The Tennessee trial court confirmed the award, and the defendant appealed. ${ }^{195}$ In particular, the defendant claimed that the arbitrator

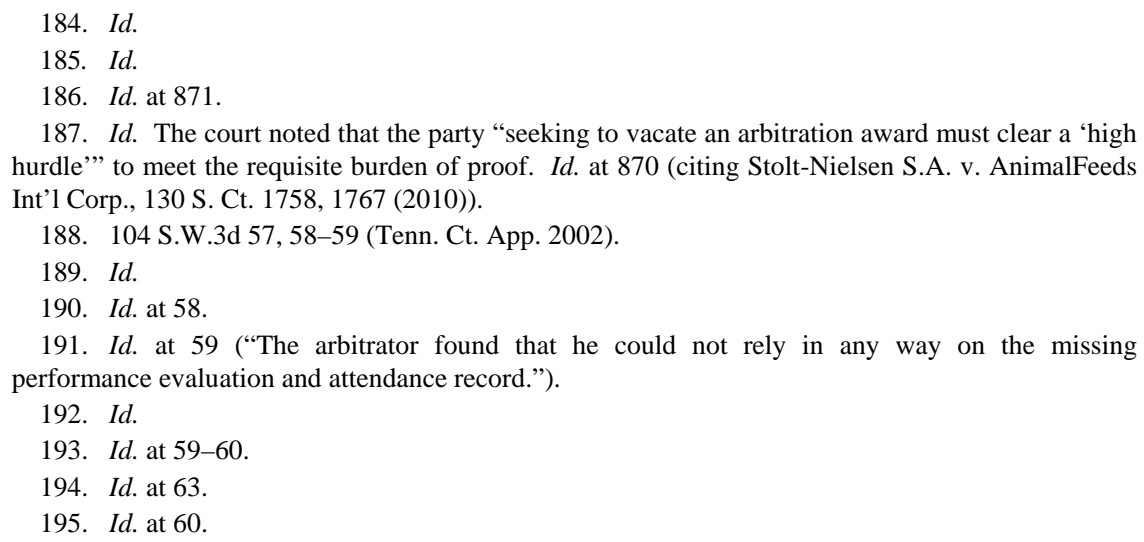


exceeded his powers by awarding punitive damages. ${ }^{196}$ The court rejected the argument out of hand, finding no such abuse of power. ${ }^{197}$

The case of AmeriCredit Financial Services, Inc. v. Oxford Management Services involved an arbitrator dismissing a claim as a sanction for spoliated evidence. ${ }^{198}$ The parties entered into an agreement that the defendant-collections company would "perform collection activities" on plaintiff's delinquent accounts receivable. ${ }^{199}$ Later, the plaintiff notified defendant of its termination of the agreement but soon discovered that the defendant had continued to collect on the delinquent accounts. ${ }^{200}$ When the parties could not resolve the dispute, the plaintiff filed a demand for arbitration pursuant to the contract. ${ }^{201}$ The defendant counterclaimed for funds allegedly owed to it, and the plaintiff moved to dismiss "based upon the spoliation of evidence," including relevant financial records. ${ }^{202}$ The arbitrator granted the plaintiff's motion, finding that the defendant " "knowingly destroyed records necessary to resolve the disputes between the parties.",203

The arbitrator thereafter awarded the plaintiff monetary damages in the amount of nearly $\$ 450,000$, and the plaintiff moved the federal court to confirm the award. ${ }^{204}$ The defendant, unsurprisingly, moved to vacate. $^{205}$ The defendant unsuccessfully argued that the arbitrator

196. Id. at 63 ("Defendant similarly argues that the arbitrator exceeded his authority by awarding punitive damages without using the magic language 'clear and convincing evidence' in his Memorandum Opinion.”).

197. Id. at 64 .

198. 627 F. Supp. 2d 85, 88 (E.D.N.Y. 2008). As noted in more detail below, the plaintiff sought to confirm the award while the defendant sought to vacate it. The defendant relied on two standards of vacatur: "exceeding his powers" under FAA § 10(a)(4), and "manifest disregard of the law." In discussing the appropriate standard of review, the court used the potentially broadest "manifest disregard" standard for vacatur, but still found the defendant's arguments for vacatur to be without merit. Id. at 94 (holding that the court "finds each of defendant's arguments, including its claim of 'manifest disregard of the law,' to be without merit.”).

199. Id. at 89

200. Id.

201. Id. at 90 ("On December 14, 2006, [the plaintiff] filed a Demand for Arbitration (the 'Demand'), against [the defendant] with the AAA, seeking the recovery of monies due and owing under the [agreement].”).

202. Id. at 90-91. The plaintiff relied on New York spoliation law in its motion. Id. at 90. Under New York law, if a party "wilfully fails to disclose information which the court finds ought to have been disclosed," the court has the power to dismiss "the action or any part thereof." Id. at 90 n.3 (quoting N.Y. C.P.L.R. 3126(3) (McKinney 1993)).

203. Id. at 91 (citing the arbitrator's findings). Note that the rule upon which the arbitrator relied specifically applied to "courts" and did not have any binding application on arbitrators. Id. at 90 \& n.3.

204. Id. at 91 .

205. Id. 
exceeded his powers in dismissing the counterclaim. ${ }^{206}$ The court found that the arbitrator had the power to resolve the matter presented in the counterclaim under the broad arbitration clause and that dismissing the counterclaim did not constitute prohibited "punitive or exemplary damages" as those terms were used in the arbitration agreement. ${ }^{207}$ The court noted that the dismissal could have been considered a penalty either for document destruction or for failure to bring competent evidence to support the claim, and it found that the arbitrator's decision could be upheld on either ground because "evidence necessary to the action was destroyed by defendant and . . . the spoliation of evidence was fatal to deciding defendant's counterclaim."208 Ultimately, "dismissal was not prohibited by the [agreement to arbitrate]."209

As these cases demonstrate, arbitrators have some liberty in awarding sanctions where parties engage in bad behavior in the arbitral forum. This type of discretion, however, is not based on any type of established rule, but it is based only on the arbitrators' assessment of equity in the given case. In fact, the arbitrators in the previous cases never pointed to directly applicable statutory or other authority in determining whether to award sanctions, instead drawing analogies to the litigation context. ${ }^{210}$ Having more explicit criminal rules ${ }^{211}$ would give arbitrators increased justification for their awards of sanctions in these types of situations.

\section{Attorney Ethics Rules on Spoliation and Document Preservation}

Apply to Arbitration in the Same Manner as Ethics Rules on Truthfulness

In addition to having attorney ethics rules that deal with truthfulness toward the tribunal, ${ }^{212}$ other ethics rules deal with truthfulness toward an

\footnotetext{
206. Id. at 94-96.

207. Id. at 96 .

208. Id. at 95-96.

209. Id. ("Regardless of whether the arbitrator dismissed defendant's counterclaim on the merits or as a procedural matter, that decision is within his broad grant of authority under the [arbitration agreement]. Therefore, the arbitrator did not exceed his authority in dismissing defendant's counterclaim.”). The district court also rejected the defendant's argument that the arbitrator violated its due process rights in dismissing the counterclaim prior to the hearing. Id. at 97.

210. See, e.g., case cited supra notes 203-04.

211. In addition, evidentiary and sanctions rules could be addressed in states' Civil Rules of Procedure or in the Rules of Evidence.

212. See supra Part III.A.2.
} 
opposing counsel and client. ${ }^{213}$ The Model Rules' provisions dealing with preservation of evidence also apply to arbitration.

The Model Rules broadly prohibit any destruction or concealment of "evidence" without any reference to the forum in which the evidence is used. ${ }^{214}$ Model Rule 3.4 prohibits an attorney from "unlawfully obstruct[ing] another party's access to evidence or unlawfully alter[ing], destroy[ing] or conceal[ing] a document or other material having potential evidentiary value. A lawyer shall not counsel or assist another person to do any such act."215 Without any limiting language, this rule applies to the arbitral forum because cases in arbitration-like litigation-are decided on evidence. The American Law Institute's(ALI) Restatement (Third) of the Law Governing Lawyers has a similarly broad rule regarding falsifying and destroying evidence. ${ }^{216}$

As with the perjury statutes, the vast majority of states adopted an evidence-tampering ethical rule. ${ }^{217}$ Given the breadth of the ruleproviding no limitation to a particular forum-it should apply to arbitration just as it applies to litigation. Accordingly, none of these ethical rules governing truthfulness need the revisions previously suggested or any other revisions in order to apply to arbitration.

\section{States Should Amend Their Criminal Laws and Ethics Rules to Make Them Applicable to Arbitration}

This Article advocates the expansion of the criminal rules for perjury and tampering, as well as the attorney ethics rules, so these laws apply to the arbitral forum. Specifically, this Article advocates that the term "official proceeding" in the MPC and similar state laws include the term

213. See Model Rules of Prof'L CONDUCt R. 3.4 (2002).

214. Id.

215. Id.

216. The Restatement (Third) of the Law Governing Lawyers has a very simple rule regarding document destruction: “(1) A lawyer may not falsify documentary or other evidence. (2) A lawyer may not destroy or obstruct another party's access to documentary or other evidence when doing so would violate a court order or other legal requirements, or counsel or assist a client to do so.” RESTATEMENT (THIRD) OF THE LAW GOVERNING LAWYERS $§ 118$ (2000). Again, this rule speaks of "evidence" broadly, so the rule facially applies to the arbitral forum; however, one of the official comments notes that evidence is usually that which may be relevant in "an official proceeding," without elaborating on the definition of the term. Id. § $118 \mathrm{cmt}$. a.

217. See supra notes 113, 119 and accompanying text. The California rule is similar, but not exactly the same as the Model Rule; it reads: "A member shall not suppress any evidence that the member or the member's client has a legal obligation to reveal or to produce.” CAL. RULES OF PROF'L CONDUCT R. 5-220 (2010). As with the Model Rules, this rule deals with evidence generally without reference to any specific application to a tribunal. 
"binding arbitration" within the definition. Prior sections discuss how the states could make those changes, noting some of the language that would successfully expand those statutes to arbitration. This section considers the policies supporting the recommended changes. ${ }^{218}$

The first subsection discusses the changing nature of arbitration and the types of cases now resolved in arbitration. The second subsection considers arbitration's status as a "quasi-judicial" forum and the application of judicial rules to the quasi-judicial forum. The third subsection considers the effect of immunity in the arbitral forum and how the extension of the criminal statues would close a current gap in the law dealing with repercussions for lying in arbitration. The fourth section considers the implications of due process requirements. Finally, the fifth section considers the implications of limited judicial review of arbitral awards, especially review for fraud.

1. Arbitration Is Considerably More Pervasive and Deals with Considerably More Legal Issues Today than at the Time of the Model Rules’ Drafting

At the time of the drafting of the original MPC, arbitration's use was considerably more limited than today and dealt primarily with factual disputes between business parties. ${ }^{219}$ Today, parties use arbitration to resolve disputes in a wide variety of contexts, including the consumer and employment contexts. ${ }^{220}$ In addition, parties now ask arbitrators to consider a broad range of legal issues, including securities violations, antitrust allegations, discrimination claims, constitutional law claims, and

218. See supra Parts III.A-B.

219. See Donald R. Philbin, Jr., Litigators Needed to Advise Transaction Lawyers On Litigation Prenups, 56 Advocate, Fall 2011, at 36-37.

220. Id. at 37 ("This national policy favoring arbitration later extended into statutory claims, including Truth in Lending, Age Discrimination in Employment Act, securities, and anti-trust. It has also been held to cover fraudulent inducement, tortious interference and intentional infliction of emotional distress, defamation and the Texas Deceptive Trade Practices Act, breach of fiduciary duty and conversion, personal injury/wrongful death, and wrongful discharge (Sabine Pilot). 'Employment arbitration grew dramatically in the wake of the Court's 1991 Gilmer decision.' . . . So arbitration is included in a wider variety of contracts than at any time, and, yet, it has 'never been subject to wider criticism.'” (citations omitted)); Larry J. Pittman, Mandatory Arbitration: Due Process and Other Constitutional Concerns, 39 CAP. U. L. REV. 853, 854 (2011) (“Arbitration is so prevalent that one can find arbitration agreements in many different types of contracts involving consumer goods, employment, bank deposits, credit cards, and a whole host of other arrangements. Frequently, businesses place non-negotiable arbitration agreements in their consumer and employment contracts, thereby, creating a mandatory arbitration system for disputes arising under such contracts." (footnote omitted)). 
class action certifications, to name just a few. ${ }^{221}$ The drafters of the MPC and the legislatures adopting perjury and tampering statutes in the 1960s and $1970 \mathrm{~s}^{222}$ likely did not consider whether these statues would be applicable to arbitration. The ALI has not released a new draft of the MPC in thirty years. ${ }^{223}$ Arbitration, however, has changed significantly

221. See Philbin, supra note 219, at 37 . When Congress passed the FAA in 1925, it likely did not intend the Act to extend to these kinds of disputes. Justice Black, in his dissent in Prima Paint Corp. v. Flood \& Conklin Mfg. Co., stated the following about Congress' intent:

[I]t is clear to me from the bill's sponsors' understanding of the function of arbitration that they never intended that the issue of fraud in the inducement be resolved by arbitration. They recognized two special values of arbitration: (1) the expertise of an arbitrator to decide factual questions in regard to the day-to-day performance of contractual obligations, and (2) the speed with which arbitration, as contrasted to litigation, could resolve disputes over performance of contracts and thus mitigate the damages and allow the parties to continue performance under the contracts. Arbitration serves neither of these functions where a contract is sought to be rescinded on the ground of fraud.

388 U.S. 395, 415 (1967) (Black, J., dissenting).

Over the last several decades, the Supreme Court's arbitrability case law clearly establishes that disputes under most statutes can be arbitrated. The only exception to this rule is if Congress specifically excludes arbitration as a dispute-resolution forum within the statute or its legislative history. Very recently, the Supreme Court decided CompuCredit Corp. v. Greenwood, which further upholds support for the arbitrability of statutory claims. 132 S. Ct 665 (2012). CompuCredit involves a class action claim by consumers under the Credit Repair Organizations Act (CROA) for alleged misrepresentations made to them regarding the available credit limits under certain credit cards and the fees associated with those cards. Id. at 668. The CROA requires that creditors give certain notices to cardholders, one of which states that the cardholders have a "right to sue a credit repair organization.” Id. at 669 (quoting 15 U.S.C. § 1679c(a) (2006)). The act also has a nonwaiver provision, meaning that any attempt by the credit repair organization to waive the protections of the statute would be void. Id. (citing 15 U.S.C. § 1679f(a) (2006)). In Compucredit, the plaintiffs received the requisite disclosure, but the contracts also had arbitration agreements. Id. at 668 .

The question for the Court was whether the arbitration agreement constituted a waiver of the "right to sue" provision, thus voiding the contractual requirement to arbitrate. Id. Unsurprisingly, the Court found the claim arbitrable and found that the requirements under the CROA are to provide a congressionally written notice to consumers, and nothing more. Id. at 672. Just as in the long line of cases culminating with Gilmer, the Court examined the legislation at issue to determine whether Congress intended to preclude the waiver of the judicial forum in cases falling under the statute. Id. at 670-71(discussing Gilmer, McMahon, and Mitsubishi). The Court found nothing in the text of the CROA that would guarantee a judicial forum but only that the power to impose liability (be it in a specific court or in arbitration) be preserved. Id. at 671-72. If Congress had intended to provide a judicial forum, the Court reasoned that the legislation should have specifically stated that arbitration of such statutory claims not be allowed. Id. at 672. Because Congress was not so specific, then the arbitration of such claims is not prohibited. Id.

222. Model Penal Code Forward (Official Draft and Explanatory Notes 1985).

223. The ALI is currently revising the sections of the MPC dealing with sentencing in order to reflect the "many changes in sentencing philosophy and practice that have taken place in the more than 40 years since the Code was first developed." Current Projects, Model Penal Code: Sentencing, AM. L. INST., http://www.ali.org/index.cfm?fuseaction=projects.proj_ip\&projectid=2 (last visited Feb. 13, 2012). Other commentators have suggested changes in the MPC sections for perjury and tampering laws in general, other than in the arbitration context. See Anthony M. Dillof, Modal Retributivism: A Theory of Sanctions for Attempts and Other Criminal Wrongs, 45 U. RICH. 
during the intervening years. Now would be a good time to revisit these statutes and make them explicitly applicable to the arbitral forum.

In 1962, arbitration applied primarily to factual disputes between businesses. ${ }^{224}$ Arbitration was not used in the employment or the consumer contexts, and arbitrators were not asked to decide legal disputes. ${ }^{225}$ The leading Supreme Court case at the time, Wilko v. Swan, held that statutory claims were inappropriate for resolution by arbitration-at least in the context of pre-dispute arbitration clauses. ${ }^{226}$ The Wilko case involved a pre-dispute agreement to arbitrate disputes falling under the Securities Act of $1933 .{ }^{227}$ The customer claimed that the seller made misrepresentations as to the value of certain securities. ${ }^{228}$ The Securities Act provided for a judicial forum for dispute resolution and an "anti-waiver" provision that would invalidate contrary provisions in a contract. ${ }^{229}$ The Court held that statutory claims were not arbitrable for two reasons. ${ }^{230}$ First, "the right to select the judicial forum ... [could not] be waived under... the Securities Act." ${ }^{231}$ Second, the Court expressed serious concern about whether arbitrators could protect

L. REV. 647, 685 (2011) (arguing that the punishment for perjury should be "de minimis" if the perjured testimony does not lead to an erroneous verdict); Monroe H. Freedman, Getting Honest About Client Perjury, 21 GeO. J. LEgal ETHICS 133 (2008) (detailing the ethical obligations of attorneys, including the opposing obligations of client confidentiality and candor towards the courts); Njeri Mathis Rutledge, Turning a Blind Eye: Perjury in Domestic Violence Cases, 39 N.M. L. REV. 149, 194 (2009) (discussing concepts of recanting in domestic abuse cases and how the perjury laws should react to those instances); Susan E. Thrower, Neither Reasonable Nor Remedial: The Hopeless Contradictions of the Legal Ethics Measures to Prevent Perjury, 58 CLEV. ST. L. REV. 781, 782-83 (2010) (requesting additional clarity from the ABA on the steps a lawyer must take when concerned that a client might commit perjury or has committed perjury); Watts, supra note 39, at 806-07 (arguing for a private qui tam cause of action against alleged perjurers; however, the text of the proposed Model Civil Perjury Act only applies for statements made "to any court of the United States”); Jerrold Abeles, Signed, Sealed \& Delivered, L.A. LAW., Apr. 2002, at 35 (advocating a change in California perjury laws in order to apply perjury laws to depositions, and problems with deposition transcripts that are not reviewed and signed).

224. Jean R. Sternlight, Creeping Mandatory Arbitration: Is It Just?, 57 StAN. L. ReV. 1631, 1635-37 (2005).

225. Id.

226. 346 U.S. 427, 438 (1953), overruled by Rodriguez de Quijas v. Shearson/Am. Express, Inc., 490 U.S. 477 (1989).

227. Id. at 429-30.

228. Id. at 428-29 ("Claiming that the loss was due to the firm's misrepresentations and omission of information concerning Mr. Page, he sought damages.”).

229. Id. at 430-33, 435.

230. Id. at 438.

231. Id. at 434-35. 
consumers' statutory rights. ${ }^{232}$ Although the Court ultimately overruled Wilko, it did not do so until $1989 .^{233}$

By 1991, the Supreme Court had completely shifted its policy on the arbitrability of statutory claims. Gilmer v. Interstate/Johnson Lane Corp. remains the leading case discussing how the arbitral forum can adequately protect statutory rights. ${ }^{234}$ The Gilmer court held that an individual employee's claims under the Age Discrimination in Employment Act (ADEA) were subject to arbitration under a pre-dispute arbitration clause. $^{235}$ The Court rejected the plaintiff-employee's contention that the ADEA claim was non-arbitrable, noting: "It is by now clear that statutory claims may be the subject of an arbitration agreement, enforceable pursuant to the FAA."236 The Court reasoned that it would uphold the parties' freedom to contract unless Congress evinced an intention that parties be disallowed from arbitrating claims arising under a particular statute. ${ }^{237}$

The Gilmer Court also clarified the statutory rights afforded by the ADEA and similar statutes. ${ }^{238}$ By the time of the Gilmer decision, the rights provided under the ADEA and other rights-based statutes constituted the underlying substantive rights-e.g., the right to a discrimination-free workplace-not the right to a judicial forum. ${ }^{239}$ In

232. Id. at 435-36.

233. See Rodriguez de Quijas v. Shearson/Am. Express, Inc., 490 U.S. 477 (1989). Following Wilko, the general consensus in the country was that statutory claims were not arbitrable. See LeRoy, supra note 2, at 157-58 (2011) (discussing the holding in Wilko and noting the beginning of the "manifest disregard" standard articulated). In 1987, the Court started to shift its view of the arbitration of statutory claims when it held that claims under the Exchange Act of 1934 were arbitrable. Shearson/Am. Express, Inc. v. McMahon, 482 U.S. 220 (1987).

234. 500 U.S. 20 (1991).

235. Id. at 23. Again, just as in Wilko, the Gilmer case involves a "one-shot" player arbitrating a dispute against a "repeat player" arising under a pre-dispute arbitration clause. See Cole \& Blankley, supra note 21, at 321 (discussing briefly the historical treatment of "one-shot" and "repeat player" parties in the arbitration forum).

236. Gilmer, 500 U.S. at 26.

237. Id. (quoting Mitsubishi Motors Corp. v. Soler Chrysler-Plymouth, Inc., 473 U.S. 614, 628 (1985)). Congress's intent would need to be manifested either in the text of the substantive statute itself or within the legislative history for the statute. Id. Ultimately, these cases turn on which policy trumps - the freedom of contract expressed in the FAA or the judicial forum provided for in the substantive statute. At the time of Wilko, the Court chose the latter. 346 U.S. 427, 434-35 (1953), overruled by Rodriguez de Quijas v. Shearson/Am. Express, Inc., 490 U.S. 477 (1989). By the time of Gilmer, the Court clearly chooses the former. 500 U.S. at 23.

238. Gilmer, 500 U.S. at 27. Note, too, that these civil rights statutes at issue were all passed well after the 1925 passage of the FAA; some of these rights - such as the rights afforded under the ADA of 1990 - arose after the promulgation of the Model Penal Code. See id. at 23, 41-42 (Stevens, J., dissenting).

239. Id. at 28-29. 
fact, the Gilmer Court went to great lengths to discuss the adequacy of the judicial forum at issue. ${ }^{240}$ The Court rejected the plaintiff's many arguments about the adequacy of the arbitral forum, including arguments that the arbitrators might be biased, that he would be afforded inadequate discovery, that the potential to limit arbitral awards would be disadvantageous to individuals, and that the scope of available remedies might be different or more limited in arbitration. ${ }^{241}$ Since the time of Gilmer, "the Court's holding has been widely applied to all kinds of claims, including other employment discrimination disputes."242

Given the changing nature of arbitration and claims subject to arbitration, now is a good time to rethink the application of perjury and tampering laws to the arbitral forum. Especially now that important statutory rights are subject to arbitration, questions about the ethics afforded in the procedure should take increased precedence. Arbitration's informality-admittedly a benefit of arbitration-should not be allowed to breed unethical behavior on the part of arbitration parties and attorneys. Now, more than ever, the rules regarding ethics within the arbitral forum should be crystallized. Extending the criminal tampering and perjury laws would go a long way toward promoting ethical behavior in the arbitral forum by arbitration participants.

\section{Arbitration Is Simply an Alternate Forum, Providing the Same Rights as a Court}

Part of the Supreme Court's acceptance of the arbitral forum is related to the Court's view that arbitration does not involve giving up rights, but rather, it provides an alternate forum in which rightsstatutory or otherwise-are vindicated. ${ }^{243}$ For parties of any kind to

240. Id. at 30. The plaintiff worked in the securities industry, and his employment agreement required arbitration under the New York Stock Exchange (NYSE) arbitration rules. Id.

241. Id. at 30-32.

242. See Pat K. Chew, Arbitral and Judicial Proceedings: Indistinguishable Justice or Justice Denied?, 46 WAKE FOREST L. REV. 185, 188 (2011). The Gilmer Court specifically left open the possibility that Congress could change civil rights laws, or any other statute, to preclude arbitration of disputes falling within the statute. To date, Congress has not responded in any significant way. In the more than twenty years since Gilmer, Congress has not amended Title VII, the ADA, the ADEA, or similar legislation to preclude arbitration thereunder.

243. The Gilmer Court specifically held: "[S]o long as the prospective litigant effectively may vindicate [his or her] statutory cause of action in the arbitral forum, the statute will continue to serve both its remedial and deterrent function." 500 U.S. at 28 (quoting Mitsubishi Motors Corp. v. Soler Chrysler-Plymouth, Inc., 473 U.S. 614, 637 (1985)); see also Michael H. LeRoy, Do Courts Create Moral Hazard? When Judges Nullify Employer Liability in Arbitrations, 93 MiNN. L. REV. 998, 
adjudicate their rights, they must be guaranteed a forum with adequate assurances that the parties and the attorneys will tell the truth and act ethically. In addition, repercussions must exist such that a person breaking these minimum standards of truth-telling and other ethical behavior could face criminal liability.

If arbitration is merely a substitute forum, then what should that forum provide? Surprisingly little has been written on the characteristics of this alternate forum as they relate to preservation of parties' substantive rights. ${ }^{244}$ One of the rights on which some commentators have focused is the right of claimants to receive the same types of remedies available in court. ${ }^{245}$ Other commentators and courts focus on a party's right to a neutral forum. ${ }^{246}$ Another of Gilmer's hallmarks is the

1007-08 (2009) ("Gilmer states a theory of forum substitution. Arbitrators serve as substitute judges. The theory implies that when arbitrators determine that evidence supports a finding of employer liability, they should provide the relief that a judge would order.”); Gary Minda \& Douglas Klein, The New Arbitral Paradigm in the Law of the Work: How the Proposed Employee Free Choice Act Reinforces Supreme Court Arbitration Decisions in Denying Free Choice in the Workplace, 2010 Mich. ST. L. REV. 51, 64 ("Gilmer, however, gave its approval to the arbitral forum as a substitute for the judicial forum only so long as the arbitral forum would allow the grievant to effectively vindicate his or her statutory claim.”). But see Kenneth T. Lopatka, A Critical Perspective on the Interplay Between Our Federal Labor and Arbitration Laws, 63 S.C. L. REV. 43, 69 (2011) (questioning whether the Gilmer distinction between forum and substance is workable beyond the "right not to be victimized by an employer's discriminatory practices or conduct").

244. But see Richard A. Bales, The Employment Due Process Protocol at Ten: Twenty Unresolved Issues, and a Focus on Conflicts of Interest, 21 OHIO ST. J. ON DISP. RESOL. 165, 191 (2005) (suggesting that limitations on damages in the arbitral forum runs afoul of Gilmer's rule that the arbitral forum is simply a substitute forum and does not substitute substance of the underlying claims); Michael H. LeRoy \& Peter Feuille, Reinventing the Enterprise Wheel: Court Review of Punitive Awards in Labor and Employment Arbitrations, 11 HARV. NEGOT. L. REV. 199, 206 (2006) (suggesting that the limitations on punitive damages under the State Farm line of cases should presumably apply in the arbitral forum if the arbitral forum is truly a substitute forum). One of the substantive rights not addressed in this Article is the right to a cost-efficient forum. Unlike the litigation forum, with publicly paid employees, arbitrators are private employees who charge the parties by the hour. If the claimant cannot vindicate rights-particularly statutory rights - in the arbitral forum because of cost concerns, then under Gilmer, the arbitration clause can be invalidated. See Green Tree Fin. Corp. v. Randolph, 531 U.S. 79, 90-92 (2000) (requiring a claimant to prove that the arbitral forum is cost prohibitive); see also Ramona L. Lampley, Is Arbitration Under Attack?: Exploring the Recent Judicial Skepticism of the Class Arbitration Waiver and Innovative Solutions to the Unsettled Legal Landscape, 18 CORNELL J.L. \& PUB. POL’Y 477, 497-98 (2009) (discussing the issue of "prohibitive costs" in vindicating rights).

245. See, e.g., Theodore J. St. Antoine, ADR in Labor and Employment Law During the Past Quarter Century, 25 ABA J. LAB. \& EMP. L. 411, 429 (2010) ("Nothing would seem more fundamental to Gilmer's thesis that mandatory arbitration merely constitutes a change of forums and not a loss of substantive statutory rights than the principle that the arbitrator must be able to provide the same remedies as a court.").

246. See, e.g., Steven M. Warshawsky, Gilmer, The Contractual Exhaustion Doctrine, and Federal Statutory Employment Discrimination Claims, 19 LAB. LAW. 285, 298-99 (2004) (“[A valid compulsory arbitration] agreement cannot require the employee to waive access to a neutral forum in 
presentation of facts-presumably untainted by perjury, fraud, or other corruption. $^{247}$

Applying perjury rules to the arbitral forum would extend to arbitration parties the same remedies that they would have in court and would help ensure that the forum remains fair. Parties in litigation have the right to seek perjury or tampering charges, and extending these criminal laws to the arbitral forum would simply provide the same remedies to parties in arbitration that they would have in court. In addition, perjury and tampering laws help ensure that the litigation forum remains a fair forum. Extending these criminal sanctions to the arbitral forum would help make arbitration a fairer process, too.

Regardless of whether the Supreme Court would go so far as to require the extension of perjury and tampering laws to the arbitral forum, ${ }^{248}$ the extension of the criminal law would certainly fall in line with Supreme Court precedent and provide additional support for legislatures to enact this type of legislation. This Article advocates making this slight change to the criminal law not because the Supreme Court would require such a change but because such a change would make the arbitral forum fairer for those parties who have chosen to resolve disputes there.

One possible criticism of this proposal might be that perjury charges are extraordinarily low and that this change would not make any real difference in the overall scheme of things. ${ }^{249}$ Often, prosecutors charge

which to enforce his or her rights.”); see also Cole v. Burns Int’l Sec. Servs., 105 F.3d 1465 (D.C. Cir. 1997); Charles J. Coleman \& Gerald C. Coleman, Toward a New Paradigm of Labor Arbitration in the Federal Courts, 13 HOFSTRA LAB. L.J. 1, 65 (1995) (noting a requirement of arbitration when statutory rights are involved: "That there be fair and regular proceedings").

247. Coleman \& Coleman, supra note 246, at 65 (noting that Gilmer also requires "[t]hat there be presentation of facts" and that "[t]he facts relating to the public policy issue must be presented to the arbitrator and the issue considered and decided by the arbitrator").

248.

The Supreme Court had already recognized but found no concern with the informality of the arbitration process itself, which, as it noted, could ignore swearing witnesses, evidence rules, transcripts, and statements of the reasons for arbitrators' determinations. In many areas the parties or the arbitration societies or sponsors had placed constraints on how the proceedings would be run to preserve notions of due process. However, there was little to control excesses that might occur in a given case and no effective appeal without a rare finding of prejudice to the complaining party.

John Kagel, Arbitration and Due Process: The Way We Were at the Time of Gilmer, 11 EMP. RTS. \& EMP. POL'Y J. 267, 298 (2007).

249. See, e.g., Erin Murphy, Manufacturing Crime: Process, Pretext, and Criminal Justice, 97 GEO. L.J. 1435, 1489-90 (2009) (noting that, while perjury charges are hard to quantify, sources indicate that as little as $0.2 \%$ of all federally filed felonies are perjury charges, and that perjury charges are more likely filed in high-profile cases or cases involving difficult issues other than the 
defendants with crimes such as perjury or tampering in order to focus on high-profile cases or to charge someone with something that will "stick." 250 Whether or not a large number of people are prosecuted for perjury, the fact that these criminal laws remain on the books is a deterrent so that people testify truthfully at trial or under oath in an official proceeding. ${ }^{251}$ Indeed, the "principal purpose of the law of perjury and false swearing must therefore be the deterrence of falsifications." ${ }^{252}$ Criminal law's extension to the arbitral forum should act as a deterrent. ${ }^{253}$

process crimes). Some commentators suggest that perjury rates are increasing, although not necessarily charges. See Linda F. Harrison, The Law of Lying: The Difficulty of Pursuing Perjury Under the Federal Perjury Statutes, 35 U. ToL. L. REV. 397, 422-23 (2003) ("Courts have recognized that 'maximum deterrence of perjury is necessarily inconsistent with maximum range for recantation.' However, the maximum deterrence of perjury is to compel truthfulness form the beginning. Of what benefit is it to give a defendant the opportunity to lie when the government knows absolutely that it cannot succeed?” (quoting United States v. Moore, 613 1029, 1041 (D.C. Cir. 1979))); Jonathan Turley, Tribunals and Tribulations: The Antithetical Elements of Military Governance in a Madisonian Democracy, 70 GEO. WASH. L. REV. 649, 681 n.191 (2002) (noting that perjury by police officers at suppression hearings is "all too common"); Alan Heinrich, Note, Clinton's Little White Lies: The Materiality Requirement for Perjury in Civil Discovery, 32 LoY. L.A. L. REV. 1303, 1319 (1999) ("If it is true that perjury is rampant-a claim that it is no doubt impossible to prove-then the systematic under-enforcement of perjury undermines the deterrent effect of the offense.” (footnote omitted)); David Sweet, Note, Sacrifice, Atonement, and Legal Ethics, 113 YALE L.J. 219, 233 n.45 (2003) ("There is a general feeling that the rate of witness perjury is ever-increasing.”).

250. See Murphy, supra note 249, at 1437 ("What do Bill Clinton, Roger Clemens, Martha Stewart, and Lil' Kim have in common? How about adding Marion Jones, Barry Bonds, Tammy Thomas, Kwame Kilpatrick, Frank Quattrone, Donald Siegelman, and Lewis Libby? The list of notable names could go on, each sharing a particular experience in common. All have been accused of a 'process crime' -an offense not against a particular person or property, but against the machinery of justice itself."); Daniel J. Seidmann \& Alex Stein, The Right to Silence Helps the Innocent: A Game-Theoretic Analysis of the Fifth Amendment Privilege, 114 HARV. L. REV. 430, 460-61 (2000) (noting that the punishment for perjury is often not high enough to warrant prosecution and that the cost of investigating and trying perjury charges would be a large social cost); Watts, supra note 39, at 782-85 (discussing the impact of low prosecution rates on the deterrent effect of perjury statutes); Ron Spears, Diogenes Visits the Home of the Testimonial Whopper, ILL. B.J., Feb. 2008, at 105 ("Rarely used tools in the truth-telling arsenal, perjury prosecutions are a clumsy deterrent.”).

251. See James v. Illinois, 493 U.S. 307, 313-14 (1990) (discussing the deterrent effect of perjury laws); Teresa A. Cheek, The Employment-at-Will Doctrine in Delaware: A Survey, 6 DEL. L. REV. 311, 316 (2003) ("[P]erjury and soliciting the commission of perjury [are] both crimes, which would have some deterrent effect on employers wishing to induce their employees to commit perjury....”); Avraham D. Tabbach, The Social Desirability of Punishment Avoidance, 26 J.L. ECON. \& ORG. 265, 266 (2010) ("The law has always attempted to deter certain avoidance efforts. Some avoidance efforts, such as perjury and obstruction of justice, are themselves deemed punishable crimes.”).

252. Michael L. Closen, To Swear ... Or Not to Swear Document Signers: The Default of Notaries Public and A Proposal to Abolish Oral Notarial Oaths, 50 Buff. L. Rev. 613, 631 (2002).

253. Simply generating awareness of a criminal law's existence might increase the positive 
Truth telling is just as important in arbitration as it is in litigation because the arbitrator is making final determinations of contested facts and law. Increasingly, arbitrators decide issues of statutory, constitutional, and other important participant rights. Without the deterrent effect of the perjury laws, parties have less incentive to tell the truth in the arbitration forum. As noted in Part I, arbitration has a reputation as being a "wild west" or "no rules" type of forum, and as such, arbitration's reputation as a fair forum is sometimes called into question. ${ }^{254}$ Extending the perjury and tampering rules to the arbitral forum would help with arbitration's reputation as a legitimate forum in which important rights can be determined by private arbitrators pursuant to the parties' agreements. ${ }^{255}$

\section{Perjury and Tampering Laws Already Extend to Other Quasi- Judicial Proceedings}

Arbitral forums are recognized as quasi-judicial forums, and as such, perjury laws should apply to them in the same manner that they apply to other judicial and quasi-judicial forums. Extending perjury laws to arbitration would simply put arbitration in line with the rules already well-established in other forums.

No question exists that arbitrations are considered quasi-judicial forums. The Restatement (Second) of Torts explicitly considers arbitration to be a quasi-judicial forum. ${ }^{256}$ Similarly, courts routinely

\footnotetext{
behavior sought by criminalizing the opposite bad behavior. For instance, the criminal law repercussions for not wearing a seat belt have by and large revolutionized the behavior of millions of U.S. drivers, who now largely all wear seat belts. The U.S. Department of Transportation reported in September 2010 that seat belt usage increased to 85\% nationwide, up from a baseline of 58\% in 1994. Traffic Safety Facts, NHTSA (Sept. 2010), http://www-nrd.nhtsa.dot.gov/Pubs/811378.pdf.

254. See supra Part I.

255. Perhaps extending these types of criminal laws to the arbitral forum would help quell some of the anti-arbitration proponents because the increased regulation of the arbitral process would help curb potential for abuse within the arbitral forum.

256. RestATEMENT (SECOND) OF TORTS $\S 585 \mathrm{cmt}$. c (1977) (including an arbitrator as a “judicial officer” for purposes of judicial immunity); $§ 586 \mathrm{cmt}$. d (noting that judicial proceedings "include all proceedings before an officer or other tribunal exercising a judicial function" and that “an arbitration proceeding may be included.”); § $587 \mathrm{cmt}$. f (same).
} 
hold that arbitrations constitute quasi-judicial forums. ${ }^{257}$ In addition, many scholars recognize that arbitration is a quasi-judicial proceeding. ${ }^{258}$

Because the perjury and tampering laws already apply to other quasijudicial forums, extension to the arbitral forum would not constitute a significant stretch. For instance, perjury laws routinely apply to the quasi-judicial forum of grand jury proceedings to encourage truthfulness of the witnesses who testify within that forum. ${ }^{259}$ Different types of quasi-judicial proceedings also fall within the reach of the perjury and tampering statutes. ${ }^{260}$ Because arbitration is already a well-recognized type of quasi-judicial proceeding, and because many other types of quasi-judicial proceedings are already subject to the perjury and tampering laws, logic dictates that arbitration, too, should be subject to these important procedural protections. ${ }^{261}$

257. See, e.g., Pfannenstiel v. Merrill Lynch, Pierce, Fenner \& Smith, 477 F.3d 1155, 1158-59 (10th Cir. 2007) (discussing arbitrations as quasi-judicial processes in the context of arbitral immunity); Portland Gen. Electric Co. v. U.S. Bank Trust Nat'l Ass'n, 218 F.3d 1085, 1090 (9th Cir. 2000) (noting that arbitrators play a quasi-judicial role when they preside over adversary hearings and admit evidence); Galuska v. NYSE, No. 99-3522, 2000 WL 347851, at *2 (7th Cir. Apr. 3, 2000) (noting that some courts consider arbitrators to be the "functional equivalent" of a judge); Fitigues, Inc. v. Varat, No. 92-4161, 1992 WL 245553 at*5 (7th Cir. Aug. 18, 1993) (describing judges as quasi-judicial officers); Lewis v. NLRB, 779 F.2d 12, 13 (6th Cir. 1985) ("Though counsel in this case meticulously avoided asking questions that would require the arbitration panel member to testify concerning the deliberations of the arbitration panel, the practice of calling a member of a quasi-judicial body to explain or otherwise embellish its decision is not permitted.").

258. See, e.g., Lisa Blomgren Bingham et al., Mediation in Employment and Creeping Legalism: Implications for Dispute Systems Design, 2010 J. DisP. RESOL. 129, 130-31 (2010) (discussing the history of labor arbitration and noting the quasi-judicial manner of arbitration that prevailed); Dennis R. Nolan, Disputatio: “Creeping Legalism” as a Declension Myth, 2010 J. DISP. RESOL. 1, 5-6 (discussing two different types of models of arbitration, noting that the more formal, quasi-judicial type of arbitration won out in the marketplace); Penny J. White, Relinquished Responsibilities, 123 HARV. L. REV. 120, 144 (2009) (arguing that due process should apply "to all judges, as well as to quasi-judicial decisionmakers, including arbitrators”); Kathryn A. Windsor, Comment, Defining Arbitrator Evident Partiality: The Catch-22 of Commercial Litigation Disputes, 6 SETON HALL CiR. REV. 191, 215 (2009) (noting that because of the quasi-judicial nature of arbitration, arbitrators should conduct extensive conflicts checks).

259. Jon Reidy et al., The Contempt Trap, 36 AM. J. CRIM. L. 39, 43-44 (2008).

260. See, e.g., James v. Ozmint, No. 1:11-1646-TMC, 2011 WL 5149185, at *2 (D.S.C. Oct. 31, 2011) (giving clerk of courts quasi-judicial immunity from perjury charge); Joshua B. Orenstein, Absolute Privilege from Defamation Claims and the Devaluing of Teachers' Professional Reputations, 2005 WIS. L. REV. 261, 264-65 (noting that a defining characteristic of a "quasijudicial” proceeding is one in which witnesses testify under penalty of perjury); Shannon L. Shaffin, Loss of Integrity May Mean Loss of the Farm: False Statements Made in Federal Water Subsidy Applications And the Doctrine of Judicial Estoppel, 15 SAN JoAQUiN AgRIC. L. REV. 1, 23 (2006) (noting that proceedings with the Bureau of Reclamation are subject to the penalty of perjury).

261. This Article does not propose changing the definition of "official proceeding" to include the term "quasi-judicial." Such a change in the MPC and state statutes across the country would likely lead to the same result as advocated here, i.e., applying these "litigation" criminal laws to the arbitral forum. This Article advocates specifically using the term "arbitration" in order to take away any 
4. Arbitral Immunity Already Extends to Arbitration Participants, So Perjury and Tampering Laws Should Also Apply

Because arbitration is a quasi-judicial forum, courts are now extending the common law rules of judicial immunity to arbitration participants. ${ }^{262}$ In other words, arbitration participants cannot be sued for defamation based on statements made within the arbitral forum. This extension of the common law rule of immunity only makes sense if the rules of perjury are also applied to arbitration. Essentially, the law has extended the benefits of immunity-i.e., protection from suit-to arbitration without also ensuring procedural safeguards exist to encourage truth-telling and to discourage lying-i.e., the criminal law. Unless state and federal legislatures change the law to apply the perjury and tampering laws to the arbitral forum, arbitration participants will be able to lie with impunity and not face any type of repercussion-civil or criminal.

Under the American legal system, no civil cause of action exists for lying in a judicial proceeding-in other words, "no American jurisdiction recognizes a common law tort cause of action for perjury."263 In addition to promoting truth-telling, ${ }^{264}$ two other important policy reasons exist for the limitation on the right to bring civil suits against parties who have engaged in misconduct in the litigation forum. First, perjury laws encourage parties to invoke the courts to resolve disputes without fear of judicial repercussion for claimed false statements and damage to reputation. Second, judicial immunity curbs the possibility of endless satellite litigation based on statements made in one judicial forum, and then the next forum, and so on, until the litigation looks and feels longer than that in Bleak House. ${ }^{265}$ This section analyzes these policy reasons for the immunity rule and how they apply to the arbitral forum, and it

doubt that arbitration fits within the scope of the statute. There already exists an argument that the laws apply to the arbitral forum. See supra Part III.A.1.a. Because that argument is admittedly weak, this Article proposes a change in the law to make the obligations of parties and attorneys working within the arbitral forum crystal clear both in scope and application.

262. This rule is being extended to all arbitration participants, including arbitrators, witnesses, and attorneys. See infra Part III.C.4.c.

263. Watts, supra note 39 , at 775-76 (footnote omitted). Watts also notes that while witness immunity usually applies to defamation claims, it also applies to claims of perjury. Id. at 776 .

264. See supra Part III.C.2.

265. Charles Dickens, Bleak House (Norman Page ed., Penguin Books 1971) (1853). Bleak House is the famous Charles Dickens novel dealing with seemingly endless litigation over an estate that lasted several generations without final resolution. 
concludes by demonstrating how the perjury rules must apply as a backstop to the potential abuses of immunity.

\section{a. Encouraging Redress of Problems Applies Equally in Arbitration}

First, immunity serves the purpose of encouraging parties to seek legal redress for their wrongs. The purpose of judicial immunitysometimes called an "absolute privilege" or "litigation privilege"-is to allow people to "speak truly ... without fear of personal liability or an expensive lawsuit."266 The litigation privilege arises from the common law. ${ }^{267}$ The subjective intent of the speaker does not matter, and the absolute privilege protects litigation participants from being subject to a

266. Dan B. DobBs, The LaW OF TorTs § 412 (2001); see also Boyd v. Bressler, 18 F. App’x. 360, 365 (6th Cir. 2001) ("In determining whether the writings or statements are reasonably related to the matter of inquiry, Ohio courts construe the absolute privilege with great liberality to assure that parties or their attorneys are not deterred from prosecuting an action vigorously for fear of personal liability.”); Harvey v. Montgomery Cnty., Tex., No. 11-CV-1815, 2012 WL 12530, at *6 (S.D. Tex. Jan. 3, 2012) ("Policy interests justifying immunity include the fact that the fear of suit may cause the prosecutor to shade his decisions instead of exercising the independence of judgment required by his public trust.” (citation omitted)); Hopkins v. O’Connor, 925 A.2d 1030, 1042 (Conn. 2007) ("Participants in a judicial process must be able to testify or otherwise take part without being hampered by fear of defamation suits.”); Simms v. Seaman, 23 A.3d 1, 13 (Conn. App. Ct. 2011) ("While no civil remedies can guard against lies, the oath and the fear of being charged with perjury are adequate to warrant an absolute privilege for a witness' statements." (citation omitted)); In re Raspanti, 8 So. 3d 526, 533-34 (La. 2009) ("Louisiana jurisprudence has consistently held that communications made in judicial or quasi-judicial proceedings carry an absolute privilege so that witnesses, bound by their oaths to tell the truth, may speak freely without fear of civil suits for damages.”); Mahoney \& Hagberg v. Newgard, 712 N.W.2d 215, 219 (Minn. Ct. App. 2006) (“The absolute immunity of witnesses and parties from claims for damages arising out of their trial testimony is premised on public policy concerns that favor 'ascertainment of truth' over selfcensorship that may result from witnesses' 'fear of subsequent liability."” (citation omitted)); Viviano v. CBS, Inc., 597 A.2d 543, 549 (N.J. Super. Ct. App. Div. 1991) (“An absolute privilege for words spoken in the course of a judicial proceeding was thought necessary to promote testimonial candor by shielding witnesses from fear of subsequent civil suits; criminal penalties were deemed sufficient sanctions against perjury.”); Sinrod v. Stone, No. 14854103, 2004 WL 6039596, at *2 (N.Y. Sup. Ct. Mar. 30, 2004) ("The public interest in maintaining high standards among members of the bar, and the necessity that persons be given a forum in which to lodge complaints without fear of being sued for libel, warrants that absolute privilege be maintained, even at the risk that some attorneys will be falsely or maliciously accused of wrongdoing.”); Ims v. Town of Portsmouth, 32 A.3d 914, 928 (R.I. 2011) ("The doctrine of absolute privilege exists because it is more important that witnesses be free from the fear of civil liability for what they say than that a person who has been defamed by their testimony have a remedy." (citation omitted)); see also Paul T. Hayden, Reconsidering the Litigator's Absolute Privilege to Defame, 54 OHIO ST. L.J. 985, 1027 (1993) ("We should recognize, in other words, that the absolute privilege, much like constitutional protections for speech, provides breathing room allowing for speech without fear.").

267. Paige Capital Mgmt., LLC v. Lerner Master Fund, LLC, 22 A.3d 710, 716 (Del. Ch. 2011) ("This absolute privilege to speak freely in relation to litigation without fear of being sued for defamation is a long-standing common law rule.”). 
defamation lawsuit based on statements made in the proceeding. ${ }^{268}$ In other words, the absolute privilege helps protect freedom of speech and a right to seek redress for wrongs.

This policy similarly applies to the arbitral forum. Parties should be able to seek redress for wrongs done to them, whether or not they have arbitration clauses, and those parties should be able to seek redress without fear of any repercussions. ${ }^{269}$ As the Supreme Court noted, arbitrators are well-equipped to resolve a wide variety of disputes, ${ }^{270}$ and immunity might help encourage parties to seek out the arbitral forum. If arbitration participants do not have any fear of civil liability for defamation based on arbitration statements, then they should feel free to bring their claims and testify truthfully and without fear at the hearings.

\section{b. Reducing Satellite Litigation}

Second, the policy supporting immunity by eliminating satellite litigation applies equally to the arbitral forum. If no immunity exists, then the losing party could sue the winning party for defamation because in cases of contested fact, the fact finder would have believed one version of the facts over the other. This type of rule would spin off endless litigation by non-winning parties. ${ }^{271}$ Courts commonly recognize immunity as a measure to curb satellite litigation. ${ }^{272}$ This point was

268. John Jay Fossett, Defamation in the Work Place: "The New Workhorse in Termination Litigation", 15 N. KY. L. REV. 93, 104 (1988) ("Absolute privilege protects the speaker notwithstanding his purpose and motive.”); Jeffrey E. Thomas, A Pragmatic Approach to Meaning in Defamation Law, 34 WAKE FOREST L. REV. 333, 365-66 (1999) ("Meaning is irrelevant to the absolute privilege because its purpose is to allow those involved in judicial, legislative, and executive proceedings to have the full freedom to express themselves without fear of being sued for defamation.").

269. See Ching v. Valencia, No. 27331, 2008 WL 3919892, at*1 (Haw. Aug. 27, 2008) (“In light of this court's policies (1) to avoid the chilling effect of possible subsequent litigation and (2) in favor of arbitration as a means of dispute resolution, a private contractual arbitration will not support a subsequent claim for malicious prosecution.”); see also Lambert v. Carneghi, 70 Cal. Rptr. 3d 626, 639-40 (Cal. Ct. App. 2008) ("The privilege protects statements made in private, contractual arbitration proceedings in order to encourage witnesses to provide open and candid testimony.”).

270. See Gilmer v. Interstate/Johnson Lane Corp., 500 U.S. 20 (1991).

271. See Restatement (SECOND) OF TORTS $§ 588 \mathrm{cmt}$. a (1977) (“The final judgment of the tribunal must be based upon the facts as shown by their testimony, and it is necessary therefore that a full disclosure not be hampered by fear of private suits for defamation.”).

272. See, e.g., McNeil v. Kennecott Utah Copper Corp., No. 2:68CV41DAK, 2009 WL 2554726, at *10 (D. Utah Aug. 18, 2009) ("An absolute privilege extends to persons whose special positions or status requires that they be as free as possible from fear that their actions in their position might subject them to legal action.” (citation omitted)); Carnegie Int'l Corp. v. Grant Thornton, LLP, No. 24-C-00-002639, 2006 WL 990960, at *2 (Md. Cir. Ct. Mar. 30 2006) ("The underlying rationale for 
eloquently expressed by the Supreme Court of Florida: "Just as participants in litigation must be free to engage in unhindered communication, so too must those participants be free to use their best judgment in prosecuting or defending a lawsuit without fear of having to defend their actions in a subsequent civil action for misconduct." ${ }^{273}$ As with the point above, judicial immunity allows the participants to avail themselves of the forum without fear of civil repercussion.

This policy reason applies equally —if not more so-to the arbitral forum. Curbing satellite litigation is an admirable policy goal no matter the forum-be it litigation or arbitration. By granting immunity to arbitral participants, attorneys and witnesses may freely testify truthfully and to the best of their ability in pursuing claims and defenses.

The reason that this policy might apply with even more force to the arbitral forum is because of arbitration's benefits of speed, efficiency, and finality. The Supreme Court recently commented that parties pursue private dispute resolution to achieve "'lower costs, greater efficiency and speed, and the ability to choose expert adjudicators to resolve specialized disputes., 274 If no immunity exists, then the arbitral process can be extended to litigation in the form of satellite litigation, such as postarbitration civil actions for defamation. In this sense, without providing immunity to arbitral participants, arbitration could become a less efficient forum compared to litigation because of the possibility that postarbitration litigation for defamation would exist for arbitral participants but not litigation participants. Accordingly, this policy serves arbitration for the same-if not better-reasons than litigation because it both reduces the fear of satellite litigation and helps ensure that arbitration remains a more efficient and cost-effective forum for dispute resolution.

the absolute privilege is to encourage participants involved in the judicial search for truth 'to do so without being hampered by the fear of private suits for defamation.”' (citation omitted)); Perdue, Brackett, Flores, Utt \& Burns v. Linebarger, Goggan, Blair, Sampson \& Meeks, L.L.P., 291 S.W.3d 448, 451 (Tex. Ct. App. 2009) ("The public policy behind the application of the absolute privilege to judicial proceedings is that the administration of justice requires full disclosure from witnesses, unhampered by fear of retaliatory suits for defamation.”); Lombardo v. Traughber, 990 S.W.2d 958, 960 (Tex. Ct. App. 1999) (“Any communication, even perjured testimony, made in the course of a judicial proceeding, cannot serve as the basis for a suit in tort.").

273. Levin, Middlebrooks, Mabie, Thomas, Mayes \& Mitchell, P.A. v. U.S. Fire Ins. Co., 639 So. 2d 606, 608 (Fla. 1994).

274. AT\&T Mobility LLC v. Concepcion, 131 S. Ct. 1740, 1751 (2011) (quoting Stolt-Nielson S.A. v. AnimalFeeds Int'l Corp., 130 S. Ct. 1758, 1775 (2010)). Concepcion did not deal with immunity or perjury and tampering, but it considered whether a California law relating to class arbitration waivers was preempted by the FAA. Id. The Court considered the hallmarks of bilateral arbitration and how bilateral arbitration differs in substantial ways from class arbitration. Id. 


\section{c. Courts Are Extending Absolute Immunity to the Arbitral Forum}

Given that the benefits of immunity extend equally to the arbitral forum, courts have begun to extend absolute immunity to that forum. ${ }^{275}$ This extension of the common law policy makes sense because the policy applies equally well-if not even more strongly - to the arbitral forum.

For example, in Kidwell v. General Motors Corp., a Florida court determined that a party's misconduct in an arbitration proceeding was covered by a judicial or quasi-judicial immunity. ${ }^{276}$ In this case, the plaintiff-customer filed a complaint against defendant and its employee, seeking to recover damages related to his purchase of a Chevrolet pickup truck. ${ }^{277}$ The plaintiff alleged that during an arbitration conducted by the Better Business Bureau (BBB) Auto Line Arbitration, the employee engaged in intentional misconduct, including lying under oath and scheming to deny the plaintiff "meaningful access to Chapter 681.",278 The defendants argued that the arbitration proceeding was judicial or quasi-judicial, and thus the employee's conduct was protected by immunity. ${ }^{279}$ The court agreed, holding that absolute immunity applied to "any act occurring during the course of a judicial or quasi-judicial proceeding, regardless of whether the act involves a defamatory

275. This section considers cases applying the immunity doctrines to arbitration participants like parties, witnesses, and attorneys. Many cases examining arbitration immunity, however, deal with whether the arbitrators are afforded immunity. These cases universally hold that arbitrators are afforded immunity. See Sacks v. Dietrich, 663 F.3d 1065, 1069 (9th Cir. 2011) (“Of course, arbitral immunity does not extend to every act of an arbitrator. Arbitral immunity extends only to those acts taken by arbitrators 'within the scope of their duties and within their jurisdiction."' (citation omitted)); DeMarco v. City of New York, No. 08-CV-3055, 2011 WL 1104178, at *3 (E.D.N.Y. Mar. 23, 2011) (recognizing absolute immunity from liability for damages to arbitrators in contractually agreed upon arbitration proceedings for all acts completed 'within the scope of the arbitral process"” (citation omitted)). Some states have statutes that specifically extend immunity to arbitrators. See, e.g., NEv. REv. STAT. ANN. § 38.229 (West 2011) (“[A]n arbitrator or an arbitral organization acting in that capacity is immune from civil liability to the same extent as a judge of a court of this State acting in a judicial capacity.”); see also Slaughter v. Am. Arbitration Ass'n, No. 2:10-CV-01437-KJD-GWF, 2011 WL 2174403, at *3 (D. Nev. June 2, 2011) (applying Nevada statute).

276. 975 So. 2d 503, 504 (Fl. Dist. Ct. App. 2007) (“[W]e agree with the trial court that [the employee] had immunity for his alleged wrongful actions because they occurred during an arbitration proceeding.").

277. Id.

278. Id. Chapter 681 is Florida's "Lemon Law," and that law specifically requires arbitration as a prerequisite for anyone seeking to make a claim in court under that law. See FLA. STAT. § 681.109 (2011).

279. Kidwell, 975 So. 2d at 504. 
statement or other tortious behavior, so long as the act has some relation to the proceeding.”280 The court rejected the plaintiff's argument that the arbitral process did not afford him due process, noting that the BBB Auto Line Arbitration program offered him the same protections as those provided in court, including "the opportunity to testify, present evidence, and cross-examine witnesses," and the ability to appeal the arbitrator's decision to the Florida New Motor Vehicle Arbitrator Board. ${ }^{281}$ Accordingly, the court found that judicial immunity applied to the arbitral proceeding and that no liability attached to the person who was accused of misconduct in arbitration in this collateral action. ${ }^{282}$

In Bushell v. Caterpillar, Inc., a plaintiff-employee challenged his discharge in arbitration pursuant to the applicable collective bargaining agreement. ${ }^{283}$ Testimony from a manager at the plant where the plaintiff worked accused the plaintiff of sleeping on the job and falsifying employment records. ${ }^{284}$ The plaintiff then filed suit for defamation against his former employer. ${ }^{285}$ In considering whether to apply the absolute privilege to arbitration, the court recognized that the purpose of the privilege is to escape liability when the defendant "is acting in furtherance of some interest of social importance, which is entitled to protection even at the expense of uncompensated harm to the plaintiff's reputation." 286 In this case, the social interest was the "free and unhindered flow of information”287 Because the arbitration hearing constituted a quasi-judicial proceeding, the defendants in the case were

280. Id. at 505 (citation omitted).

281. Id. (citing FLA. StAT. § 681.109). The decision also notes that the plaintiff failed to appeal the adverse award. Id.

282. The opinion does not state whether an appeal on these same grounds would have been successful. Id. at 504-05.

283. 683 N.E.2d 1286, 1287 (Ill. App. Ct. 1997).

284. Id.

285. Id.

286. Id.

287. Id. The court also relied on the Restatement (Second) of Torts for authority that arbitral proceedings should be covered by absolute privilege. Id. at 1288 (citing RESTATEMENT (SECOND) OF TORTS §§ 587, 588 (1977)). The court found arbitration to constitute a "quasi-judicial” tribunal under Illinois law. Id. at 1288-89 ("Under Illinois law, a tribunal is quasi-judicial when its [sic] possesses powers and duties to (1) exercise judgment and discretion; (2) hear and determine or ascertain facts and decide; (3) make binding orders and judgments; (4) affect the personal or property rights of private persons; (5) examine witnesses, compel the attendance of witnesses, and hear the litigation of issues on a hearing; and (6) enforce decisions or impose penalties." (citing Adco Servs., Inc. v. Bullard, 628 N.E.2d 772, 774-75 (Ill. App. Ct. 1993)). 
afforded "absolute immun[ity] from suit for communications made in plaintiff's arbitration hearing.,"288

The Maryland case of Odyniec v. Schneider ${ }^{289}$ demonstrates why applying absolute immunity to the arbitral forum serves the important goals underlying the doctrine. Odyniec involved plaintiffs who sued an expert witness for defamation based on statements made in an arbitration. ${ }^{290}$ The underlying arbitration involved a medical malpractice claim against certain doctors, the plaintiffs in Odyniec. ${ }^{291}$ The defendant in the civil case was hired as an expert witness by the defense at arbitration, and during a pre-hearing consultation the expert witnessdefendant stated to the injured claimant that the plaintiff-doctors provided false statements and performed needless surgery. ${ }^{292}$ The plaintiff-doctors then sued expert witness-defendant for defamation. The court recognized the underlying policies behind the judicial privilege: "[b]ecause the need for participants to speak freely during judicial proceedings is so essential to the judicial process, the individual's right to redress for defamation is necessarily curtailed."293 The court extended immunity to expert witness, even though the statement was unsolicited and not even made during the arbitration hearing, because the purposes of immunity would be satisfied. ${ }^{294}$ Ultimately, the court determined that "the social benefit derived from free and candid participation by potential witnesses in the arbitration process is essential to achieve the goal of a fair and just resolution of claims of malpractice against health care providers."295 Thus, the

\footnotetext{
288. Id. at 1289.

289. 588 A.2d 786 (Md. 1991).

290. Id. at 787-88.

291. Id. at 787.

292. Id. at 788.

293. Id. at 790 (citation omitted).

294. Id. at 793 ("That [the defendant's] defamatory statement may have been gratuitous, unsolicited, and in part irrelevant to the purpose for which he was employed, and was not made during the actual hearing before the arbitration panel, does not defeat the absolute privilege. Whatever [the defendant's] motivation may have been, he made his verbal statement to [the patient], a party in the then-pending arbitration proceeding, while he was conducting a medical examination of her in preparation for his participation in that proceeding. It was thus made in the course of his participation in that pending proceeding and therefore, without regard to its relevance, the verbal statement is accorded the same absolute privilege as if it had been made by a witness during the arbitration hearing itself.”).

295. Id.; see also Yeung v. Maric, 232 P.3d 1281, 1285 (Ariz. Ct. App. 2010). The Yeung court extended the privilege to a physician witness in an arbitration and observed: "These principles support a corresponding immunity for witnesses who participate in arbitration proceedings. Arbitrators perform quasi-judicial functions, and arbitration proceedings are quasi-judicial in nature.
} 
important social policies underlying immunity caused the Maryland court to apply immunity to the arbitral forum.

As these cases demonstrate, courts have not hesitated to extend the litigation immunity to the arbitral forum for all of the same reasons that the immunity exists in the first place. None of these cases, however, consider the applicability of the perjury and tampering laws to the arbitral forum.

d. The Criminal Perjury and Tampering Laws Must Be Extended to the Arbitral Forum to Prevent Arbitration from Becoming an Ethical "Black Hole"

Because the policies supporting civil immunity apply to arbitration, the extension of immunity to the arbitral forum makes perfect sense. Immunity, however, is only one side of the coin. The purpose of the perjury and tampering statutes is to provide some repercussion in the event that the parties do not act ethically and truthfully. By not extending the perjury and tampering laws to the arbitral forum, the courts have created an ethical "black hole" around the arbitral forum. ${ }^{296}$

Witnesses in private, contractual uninsured/underinsured motorist coverage arbitration proceedings should generally be covered by the absolute privilege regarding defamatory statements, assuming the statements are related to the proceeding and basic procedural safeguards are present in the proceeding." Id. (citation omitted).

296. Not all commentators agree with the extension of immunity to arbitration. See, e.g., Peter Rutledge, Market Solutions to Market Problems: Re-Examining Arbitral Immunity As a Solution to Unfairness in Securities Arbitration, 26 PACE L. REV. 113, 116 (2005) (recommending replacing arbitrator and provider immunity with damage caps and liability waivers); Emmanuela Truli, Liability v. Quasi-Judicial Immunity of the Arbitrator: The Case Against Absolute Arbitral Immunity, 17 AM. REV. INT'L ARB. 383, 384-85 (2006) (skeptical of immunity in the context of international arbitrations); Maureen A. Weston, Reexamining Arbitral Immunity in an Age of Mandatory and Professional Arbitration, 88 MinN. L. REV. 449, 460 (2004) (arguing that a rule of qualified immunity for arbitrators is better than utilizing the rule of absolute immunity); W. Monroe Bonnheim, Note, Immunity and Justice for All: Has the Second Circuit Overextended the Doctrine of Absolute Immunity by Applying It to Arbitration Witnesses?, 2009 J. DisP. RESOL. 213, 224 (suggesting that courts are extending immunity without thoroughly considering the situation); Meredith Goldich, Comment, Throwing Out the Threshhold: Analyzing the Severability Conundrum Under Rent-A-Center, West, Inc. v. Jackson, 60 AM. U. L. REV. 1673, 1681 (2011) (“In addition to reviewability problems, arbitrators often remain immune from malpractice suits, and unlike judges, arbitrators' decisions are not available to the public. The lack of judicial review, combined with arbitrators' malpractice immunity, may deprive arbitration claimants of protection from the mistakes of arbitrators.”); Sarah Roitman, Note, Beyond Reproach: Has the Doctrine of Arbitral Immunity Been Extended Too Far For Arbitration Sponsoring Firms, 51 B.C. L. REV. 557, 566 (2010) (calling for a legislative change to remedy the perceived problem of over-extension of immunity to arbitral providers). But see Michael D. Moberly, Immunizing Arbitrators From Claims of Equitable Relief, 5 PEPP. DisP. RESOL. L.J. 325, 327-28 (2005) (arguing that arbitrators should be immune from, among other things, claims for equitable relief). 
Immunity without a corresponding criminal law disincentivizes good behavior for arbitration participants-especially for non-lawyers who are not otherwise bound by the codes of attorney ethics.

To correct this imbalance, legislatures should extend the perjury and tampering laws to the arbitral forum. Simply by amending the definition of "official proceeding" to include arbitration specifically, state legislatures will go a long way toward promoting accountability and ethics for arbitral participants.

\section{Arbitral Providers Recognize the Need for a Fair Forum, but None Specify Repercussions for Party or Attorney Unethical Behavior}

Fairness issues also dictate the ethical behavior of attorneys and parties in the arbitral forum, but the ethical role of attorneys and parties has long remained unaddressed by the arbitral forums and their ethical rules. Many arbitral-provider organizations have rules addressing ethics for neutrals. ${ }^{297}$ The providers, however, do not have similar rules regarding participant-attorney and party-behavior. The provider organizations' failure to regulate participant conduct is further reason why the criminal law should address this gap in both the law and the way that arbitral providers regulate the process.

In the 1990s, many of the arbitral providers began instituting codes of ethics and protocols to make the arbitration process fairer and to respond to criticisms of the arbitral process. ${ }^{298}$ For instance, the

297. Steven W. Suflas, From Litigation to Arbitration, and Back Again?, in The Role of ETHICS IN ADR: LEADING LAWYERS ON UNDERSTANDING THE ETHICAL OBLIGATION OF Attorneys Engaging in Alternative Dispute Resolution, at 2 (2011) ("The ethics rules in arbitration emanate from a number of different sources. The National Academy of Arbitrators has published its Code of Professional Responsibility for Arbitrators of Labor Management Disputes. JAMS has its own code, entitled Arbitrators' Ethics Guidelines, and the AAA has published a Code of Ethics for Arbitrators in Commercial Disputes. There are also separate rules governing labor and employment disputes in various states. In my home state, the New Jersey State Board of Mediation has its own rules for arbitration procedures. Thus, at the outset, both lawyers and arbitrators must determine and digest the rules that will apply to a particular proceeding, keeping a keen eye on the general ethical rules of the jurisdiction in which the arbitration takes place, as well as the rules of the states that license the participants.”).

298. The timing of these documents is not coincidental. The arbitral providers began addressing issues of fairness in arbitration in a more systematic way following the Gilmer decision and the increased use of arbitration to hear statutory claims. See supra Part III.C.1 (discussing the changing nature of arbitration; see also SUFLAS, supra note 297 ("In the aftermath of the Supreme Court opinion in Gilmer and its progeny, the procedural rules governing many employment arbitrations changed significantly, and for an interesting reason. In the face of a judicial call for greater use of ADR, plaintiffs' lawyers who represent employees in these cases went to Judicial Arbitration and Mediation Services Inc. (JAMS) and the American Arbitration Association (AAA) - the two primary 
American Arbitration Association (AAA) implemented an Employment Due Process Protocol in $1995^{299}$ and a Consumer Due Process Protocol in $1998^{300}$ to address these fairness issues. The purposes of these protocols is to regulate the forum and the neutrals-not necessarily the parties' or attorneys' conduct. ${ }^{301}$ These Protocols require safeguards such as:

[Q]ualified, independent, and impartial neutrals chosen by an equal voice of the parties, an independent administration, reasonable cost which may require the business rather than the consumer to pay, a reasonably convenient location, reasonable time limits, a right to representation, encouragement of mediation, clear notice of the arbitration provisions and their consequences, access to information to ensure a fair hearing, a fair hearing, availability of all remedies that would be available in court, application by the arbitrator of pertinent contract terms, statutes and legal precedents and, on request, the provision of an explanation of the basis for the award. ${ }^{302}$

These safeguards only address issues within the forum's control or the arbitrator's control—and not participant conduct. ${ }^{303}$ The focus of

providers of arbitrators and arbitration processes-and threatened a boycott unless the agencies developed rules that provided adequate procedural protections for their clients. The result was the convening of a Task Force on Alternative Dispute Resolution in Employment, which published a due process protocol for mediation and arbitration of statutory disputes arising out of the employment relationship. Both JAMS and the AAA responded with rules that provided for more discovery than had originally existed.”)

299. Am. Arbitration Ass’n, Employment Due Process Protocol (2011 Revised Version), available at http://www.adr.org (highlight "Rules \& Procedures,” then click “Codes \& Protocols”).

300. NAT'L CONSUMER Disputes AdVisory COMM. \& AM. ARBITRATION Ass'N, CONSUMER DuE Process Protocol (2007), available at http://www.adr.org (highlight "Rules \& Procedures," then click Codes \& Protocols”).

301. See Edna Sussman, The Dodd-Frank Act: Seeking Fairness and the Public Interest in Consumer Arbitration, N.Y. DisP. RESOL. LAW., Fall 2011, at 29, available at http://www.sussmanadr.com/docs/Dodd\%20Frank\%20NYSBA\%20version\%20\%20fall\%202011.pd f (last visited Feb. 14, 2011) (discussing private sector arbitration protocols put in place by the American Arbitration Association).

302. Id.

303. Id. The provider organizations may be concerned that they do not have jurisdiction to govern private party conduct, and thus focus on issues well within their control. The provider organizations, however, could regulate attorney and participant conduct by instituting sanctions for violating parties. Those sanctions could include things such as withdrawing from the case or preventing an offending attorney from receiving services from that provider again. The criminal law is not the only potential remedy. The provider organizations could also take steps to prevent participant misbehavior. Given the providers' current unwillingness to police participant misconduct directly, an extension of the criminal law to the arbitral forum is particularly pressing. As support for the argument that arbitral providers are capable of self-regulation, see Christopher R. Drahozal \& Peter B. Rutledge, Contract and Procedure, 94 MARQ. L. REV. 1103, 1128-29 (2011) (discussing how due process protocols are the forum's method of self-policing and discussing the scope of the 
these protocols largely concerns parties' rights to representation, discovery, fairness in procedure, and availability of remedies. ${ }^{304}$ But these protocols do not deal with participant responsibilities-only participant rights. ${ }^{305}$ In other words, the private marketplace has an enforcement gap with respect to party conduct, and an extension of the criminal law to arbitration would fill this gap.

In a similar vein, the Codes of Ethics promulgated by the provider organizations deal with arbitrator ethics-not participant ethics. ${ }^{306}$ The Code of Ethics for Commercial Arbitrators, revised in 2004, facially only applies to arbitrators. ${ }^{307}$ The Code provides that the "arbitrator should uphold the integrity and fairness of the arbitration process" by ensuring that arbitrators are free from bias and are competent to hear the cases before them. $^{308}$ The JAMS ethical guidelines similarly provide that an "arbitrator should uphold the dignity and integrity of the office of the arbitration process." ${ }^{09}$ Again, the arbitral providers have had success

protocols).

304. See Sussman, supra note 301.

305. Id.

306. See, e.g., Am. Arbitration Ass'N, The Code of Ethics in Commercial Disputes (2011), available at http://www.adr.org (highlight "Rules \& Procedures," then click "Codes \& Protocols”). Of course, not all arbitrations are conducted through an arbitral provider. One of the benefits of arbitration is its flexibility and ability to use any arbitrator of the parties' choosing. See Henry Gabriel \& Anjanette H. Raymond, Ethics for Commercial Arbitrators: Basic Principles and Emerging Standards, 5 WYO. L. REV. 453, 454 (2005) (noting that arbitrators are generally appointed by the parties or nominated by the arbitral institution). Arbitration outside of a provider organization, called ad hoc arbitration, remains completely unregulated outside of state law and the FAA - neither of which directly govern issues such as participant misconduct. See Jacob R. Shaffer, Rescuing the Arbitral Model: Identifying the Problem in Natural Resources Trade and Development, 114 W. VA. L. REV. 309, 313-14 (2011) (noting that the rules and procedures in ad hoc arbitrations are chosen in advance or on the fly by the parties). The fact that arbitration occurs outside of the provider organizations (and is otherwise unregulated) is another reason to extend the criminal law to apply to arbitration participants when those participants lie and tamper with witnesses and evidence.

307. Am. Bar Ass'n \& Am. Arbitration. Ass'n, CODE of Ethics FOR Arbitrators in COMMERCIAL DISPUTES (2004), available at http://www.americanbar.org/content/dam/aba/migrated/ dispute/commercial_disputes.authcheckdam.pdf. Both the AAA and the ABA worked together to promulgate these rules. The intent of these rules is to regulate arbitrator's behavior when working under the rules of the AAA.

308. Id. Canon I (2004) (emphasis added). Fairness and impartiality of neutrals was the primary concern of the drafters of the 2004 revisions to the AAA/ABA Code of Ethics. Bruce Meyerson \& John M. Townsend, Revised Code of Ethics for Commercial Arbitrators Explained, 59 DISP. RESO. J. 10, 11 (2004) ("The most fundamental and far-reaching change contained in the 2004 Revision is the application of a presumption of neutrality to all arbitrators, including party-appointed arbitrators.”).

309. JAMS, ARBITRATORS ETHICS GUIDELINES I, available at http://www.jamsadr.com/ arbitrators-ethics/. In the area of labor and employment arbitrations, the AAA Code of Professional Responsibility for Arbitrators of Labor-Management Disputes similarly only applies to the arbitrators and not to other arbitration participants. AM. ARBITRATION Ass'N, CODE OF 
regulating the arbitrators, but they have not regulated the participants in any meaningful way.

Perhaps this focus on arbitrators is short-sighted given the possibility that not just the arbitrators, but the participants might be causing some of the problems in arbitration. ${ }^{310}$ While certainly both the criminal law and the rules of the arbitral providers could prohibit this conduct, extending the criminal law appears to be the more viable alternative given the gap in marketplace regulation.

\section{Judicial Review Is Currently Unduly Limited in Scope for Dealing with Participant Misconduct}

A final reason that the criminal law should be amended to criminalize arbitral perjury and tampering is because it provides a second forum to achieve redress of litigation problems, other than the limited judicial review available under section 10 of the FAA. ${ }^{311}$ Two issues arise, in particular, with respect to judicial review. First, litigants in court have the opportunity to both appeal ${ }^{312}$ and attempt to institute charges with the prosecutor for perjury and tampering. As noted above,

PROFESSIONAL RESPONSIBILITY FOR ARBITRATORS OF LABOR-MANAGEMENT DispuTES (2011), available at http://www.adr.org (highlight "Arbitrators \& Mediators," then click "Codes of Ethics" and "Labor Neutrals Code of Professional Responsibility").

310. Perhaps one of the reasons why a code of ethics governing participant behavior has not been created yet is because no such problem has been perceived to exist. This argument, however, does not hold true when considering the fact that arbitrator misconduct was not a significant problem at the time of the adoption of the model codes. Meyerson \& Townsend, supra note 308, at 10 (noting that the creation of the AAA/ABA Code of Ethics was not spurred by actual problems with arbitrator misconduct, but because of a genuine concern for improving the arbitral process). Perhaps outside pressure-particularly from the plaintiff/claimant bar-forced the creation of some of these ethical codes with respect to arbitrators, and similar outside pressure currently does not exist regarding attorney and participant conduct.

311. 9 U.S.C. $§ 10(a)$ (2006). Judicial review under section 10 is extremely limited, even in cases of fraud and other misconduct. See supra note 1.

312. Admittedly, the standard of review available to a litigant in court is different than a party in arbitration; however, this Article does not suggest broadening the standard of review provided in FAA section 10(a), even with respect to the review for fraud. As noted in Part II, the parties bargained for arbitration under general contract law, and part of the bargain is limited judicial review under FAA section 10. Limited judicial review promotes the concepts of finality, see supra Part III.C.4.b, and this Article does not suggest altering that balance between review and finality. Adding potential criminal violation would simply afford arbitration participants additional rights - but limited rights that are in the power of a third-party prosecutor, as opposed to themselves in private litigation for defamation and other causes of action. See supra Part III.C.4.c (discussing the benefits of absolute immunity in the context of arbitration). Even if the extension of the criminal law to arbitration mostly just provides a greater deterrent effect, that effect still promotes the fairness of arbitration. See supra notes 251-53 and accompanying text (regarding the deterrent effect of the criminal law and how the criminal law can change behavior in a socially positive manner). 
the lack of perjury proceedings leaves arbitration advocates with only one recourse-limited review under section 10 of the FAA. Second, the review under section 10 is limited compared with litigation appellate review. The existence of limited judicial review ${ }^{313}$ supports the extension of criminal law in these situations to the arbitral forum. These ideas are addressed in turn.

a. Extension of the Criminal Law Regarding Perjury and Tampering Would Place Arbitration Participants on Equal Footing with Litigation Participants in Terms of Avenues for Review

First, litigation parties have two judicial avenues ${ }^{314}$ for dealing with serious misbehavior in the litigation process, namely perjury or tampering. Litigants are free to appeal decisions tainted by such misconduct under normal appellate rules. ${ }^{315}$ Litigants also have the option of asking the prosecutor to bring criminal charges against the perpetrator of the misconduct. Arbitration parties, while possessing some limited rights to appeal, are foreclosed from this second avenue of pursuing redress for grievous misconduct. In other words, litigants have two proverbial bites at the apple, while arbitration participants only have one.

Providing arbitration participants with an opportunity to seek redress from the prosecutor would extend to those participants an important right relating to having claims resolved in a neutral and unbiased forum. Such extension of the criminal law would well serve the policies set forth in the Supreme Court's Gilmer decision. Under Gilmer and the subsequent cases, the Court expressed concern about adequately vindicating statutory rights in the arbitral forum. The Court considered challenges to fairness in arbitration, such as arbitrator bias, adequacy of discovery, adequacy of arbitral awards, availability of relief, and unequal bargaining

313. This Article does not advocate changing the standard of review under the Federal Arbitration Act. Other scholars have advocated for expanded judicial review as a way of remedying certain perceived injustices in the arbitral forum. See, e.g., Pittman, supra note 220, at 874 (advocating expanded judicial review for all adhesion, mandatory arbitration agreements).

314. Admittedly, other avenues also exist, including filing a disciplinary action against an attorney who has violated the ethical rules discussed above, or perhaps even a claim of malpractice against an attorney. Self-help remedies (not endorsed by this Article) hypothetically also exist, but this section attempts to deal with the primary judicial remedies available to litigants.

315. This avenue is - to a lesser extent-available to arbitration participants. See infra Part III.C.6.b. 
power. ${ }^{316}$ By affording arbitral participants the right to ask the prosecutor to pursue criminal charges for wrongdoing in the arbitral forum, such law would further the policy set forth in Gilmerparticularly as it relates to the availability of remedies.

b. Given Arbitration's Limited Review, Criminal Remedies in the Event of Serious Misconduct Would Make the Forum Fairer

Second, limited review of arbitration awards - in and of itselfsupports the extension of the criminal law to allegations of perjury and tampering in the arbitral forum. Review of arbitral awards is necessarily limited in order to promote the laudable policy of arbitration finality. Limited review does not, however, always cover wrongs such as perjury or tampering. Therefore, limited review weighs in favor of extending the criminal law to provide some remedy for serious misconduct in the arbitral forum.

The FAA provides that an award may be vacated, inter alia, if it is procured by fraud. ${ }^{317}$ Fraud, however, is difficult to prove in the arbitration context. ${ }^{318}$ To prove fraud in this context, an arbitration party must meet the following test: "that the fraud was (1) not discoverable upon the exercise of due diligence prior to the arbitration, (2) materially related to an issue in the arbitration, and (3) established by clear and convincing evidence." ${ }^{319}$ This standard of review is unlike any other

316. Gilmer v. Interstate/Johnson Lane Corp., 500 U.S. 20, 30-33 (1991).

317. 9 U.S.C. § 10(a)(1) (2006) ("In any of the following cases the United States court in and for the district wherein the award was made may make an order vacating the award upon the application of any party to the arbitration... where the award was procured by corruption, fraud, or undue means ....”). The FAA has a handful of limited grounds for vacatur, but the one most often invoked in situations involving perjury or tampering is the exception for fraud. See, e.g., In re Arbitration Between Trans Chem. Ltd. \& China Nat'l Mach. Imp. \& Exp. Corp., 978 F. Supp. 266, 304 (S.D. Tex. 1997) ("Fraud requires a showing of bad faith during the arbitration proceedings, such as ... willfully destroying or withholding evidence ...." (citations omitted)), aff'd per curiam sub nom. Trans Chem. Ltd. V. China Nat'l Mach. Imp. \& Exp. Corp.) 161 F.3d 314 (5th Cir. 1998).

318. Fraud is often difficult to prove in any context. Usually, a showing of fraud requires pleading with particularity. See, e.g., Fed. R. Civ. P. 9(b), (“[A] party must state with particularity the circumstances constituting fraud."). Often fraud has a heightened burden of proof. See infra note 319 and accompanying text. Fraud in the context of arbitration is different than fraud generally, but it is still difficult to prove. See Pac. \& Arctic Ry. \& Navigation Co. v. United Transp. Co., 952 F.2d 1144, 1147-48 (9th Cir. 1991) (discussing what constituted fraud at common law and what fraud can mean in an arbitration scenario).

319. Lafarge Conseils Et Etudes, S.A. v. Kaiser Cement \& Gypsum Corp., 791 F.2d 1334, 1339 (9th Cir. 1986) (citing Dogherra v. Safeway Stores, Inc., 679 F.2d 1293, 1297 (9th Cir. 1982)) (affirming confirmation of an arbitration award despite allegations of document falsification because the information was discoverable with the exercise of due diligence); see also Smith W., LLC v. 
under the FAA. Generally, the grounds for review, while limited under FAA section 10, are examined by the trial court on a de novo basis. ${ }^{320}$ The review for fraud - the most likely review applicable here-is even more limited than the other avenues for review given the higher burden of proof. ${ }^{321}$ Unsurprisingly, courts have frequently held that plaintiffs failed to meet this burden of proof in situations involving alleged perjury and evidence tampering. ${ }^{322}$ Parties that submitted-and lost-the issue of fraud or tampering to the arbitrator fare particularly poorly in post-

Mognach Payne Inc., No. 1CA-CV09-0568, 2010 WL 2471051, at*2 (Ariz. Ct. App. June 17, 2010) (“[A] party seeking to vacate an arbitration award claiming fraud must show 'that the fraud was (1) not discoverable upon the exercise of due diligence prior to the arbitration, (2) materially related to an issue in the arbitration, and (3) established by clear and convincing evidence."” (quoting Lafarge, 791 F.2d at 1339)). This test appears to be the test that a majority of the courts employ when confronted with a motion for vacatur on the grounds of fraud. Other tests are employed in a minority of jurisdictions. See, e.g., Prof'l Builders, Inc. v. Sedan Floral, Inc., 819 P.2d 1254, 1258 (Kan. Ct. App. 1991) (discussing the rule articulated in C.J.S.); 6 C.J.S. Arbitration § 202 (2004) ("As a general rule any fraud or misconduct having a tendency to affect the award improperly will vitiate it and render it subject to impeachment.”).

320. The standard of review and the grounds for vacatur are often conflated. The grounds for review are limited to things such as fraud, misconduct, or arbitrators exceeding their powers. Great Am. Ins. Co. v. Moye, 733 F. Supp. 2d 1298, 1302 (M.D. Fla. 2010) (citing 9 U.S.C. § 10(a)). To vacate an award, a trial court must make findings that specific types of misconduct occurred, such as fraud, bias, and exceeding powers. See Braata, Inc. v. Oneida Storage Co., 251 P.3d 584, 588 (Colo. App. 2010) (interpreting a state statute to require a finding that an arbitrator engaged in misconduct to vacate an arbitration award). The burden of proving these elements by a party seeking vacatur is often an overlooked portion of the analysis, but some courts do recognize that the burden is generally decided by the trial court on a de novo basis. See, e.g., Allstate N. J. Ins. Co. v. Driscoll, No. C-6209-09, 2011 WL 408837, at *2 (N.J. Super. Ct. App. Div. Feb. 9, 2011) ("Where, as here, a party seeks to vacate an award pursuant to N.J.S.A. 2A:23A-13c(3), the trial court ' [s] hall make an independent determination of any facts relevant [to the application for vacating the award] de novo, upon such record as may exist or as it may determine in a summary expedited proceeding.'”); Braata, 251 P.3d at 588 ("The latter issue is explicitly assigned to the court to decide by section 1322-206(2), C.R.S.2009, and each of the other bases to vacate necessarily requires de novo findings by a court.").

321. See supra text accompanying note 319 (laying out the burden of proof for fraud).

322. Molten Metal Equip. Innovations v. Pyrotek, Inc., No. 1:10cv388, 2010 WL 2639912, at *2 (N.D. Ohio June 29, 2010) (holding that, under the same test, no clear and convincing evidence of fraud existed that was not already presented to the arbitrator, and further noting that the reason for the rule is that a broader review would "undermine a substantive determination made by the arbitrator”); Site, Inc. v. Peabody Constr. Co., Inc., No. 06-P-1229, 2007 WL 2458482, at *2 (Mass. App. Ct. Aug. 30, 2007) ("In addition, the court held that perjury itself does not constitute fraud for the purposes of vacating a judgment where the moving party cannot demonstrate that the judicial process itself was corrupted by the perjury.” (citing Wojcicki v. Caragher, 849 N.E.2d 1258, 1266 (Mass. 2006))); Artco, Inc. v. DiFruscia, 365 N.E.2d 832 (Mass. App. Ct. 1977) (“There is no fraud upon the court where a judgment has been 'obtained with the aid of a witness who, on the basis of after-discovered evidence, is believed possibly to have been guilty of perjury.'” (quoting Hazel-Atlas Glass Co. v. Hartford-Empire Co., 322 U.S. 238, 245 (1944))); Groves v. Merrill, Lynch, Pierce, Fenner \& Smith, Inc., No. MER-L-1471-04, 2006 WL 2059514, at *6 (N.J. Super. Ct. App. Div. July 26, 2006) (finding movant did not establish fraud based on alleged document tampering when the arbitrator considered the issue in the first instance). 
arbitration litigation on the bases that the arbitrator had considered the issue and that review is quite limited. ${ }^{323}$ Thus, extending the criminal laws of tampering and perjury to the arbitral forum would provide needed remedies - albeit different types of remedies - to those who have been the victims of arbitration-participant misconduct.

While the "clear and convincing" evidence burden likely stems from the burden of proof for civil fraud, ${ }^{324}$ the application to the arbitral forum makes little sense. ${ }^{325}$ Parties seeking to vacate an arbitration award on the basis of fraud are not trying to prove a cause of action for fraud. These parties only seek to show that fraud existed such that an arbitral

323. See Clyde Bergemann, Inc. v. Sullivan, Higgins \& Brion, Civil No. 08-162-KI, 2008 WL 4279632 , at $* 2$ (D. Or. Sept. 18, 2008) (“[The plaintiff] also argues that it is prejudiced by defendants' delay in seeking arbitration because of defendants' alleged spoliation of evidence. I am unpersuaded by [the plaintiff's] contention that the arbitrator cannot appropriately remedy the situation, if he concludes that the allegations are true.”); Gateway Funding Diversified Mortg. Servs., L.P. v. Field, Civil Action No. 04-4428, 2008 WL 2758877, at *5, *8-9 (E.D. Pa. July 10, 2008) (confirming arbitration award despite arguments that one party destroyed documents when the arbitrator considered the issue on a full record and refused to apply an adverse inference); Jones v. Dykstra, No. B196521, 2008 WL 4901080, at *5 (Cal. Ct. App. Nov. 17, 2008) (affirming confirmation of award because, under California law, judgment cannot be vacated on fraud presented in the former action, as "intrinsic" fraud); Banc of Am. Inv. Servs., Inc. v. Plycraft Indus., No. B168627, 2005 WL 905927, at*1 (Cal. Ct. App. Apr. 20, 2005) (enjoining a claim of spoliation from proceeding in arbitration under the doctrine of res judicata when the plaintiff failed to bring such a claim in a first arbitration against Banc of America and the plaintiff actually used evidence of the missing documentation in the first arbitration).

Note, however, that the opposite is true, too. If the arbitrator awards damages because of participant misconduct, that award will also be subject to quite limited review and likely confirmed. See, e.g., Hendrik Delivery Serv., Inc. v. St. Louis Post-Dispatch LLC, No. 4:07CV1516 JCH, 2007 WL 3071827, at *8-9 (E.D. Mo. Oct. 19, 2007) (confirming an award in which an arbitrator awarded punitive damages, in part, because of the respondent's destruction of documents and failure to create a record of information pertinent to the upcoming arbitration).

324. See, e.g., Kelly v. VinZant, 197 P.3d 803, 809 (Kan. 2008) (requiring a plaintiff to prove the following elements of fraud by clear and convincing evidence: (1) a false statement of material fact; (2) that was known to be false or was recklessly made without knowledge concerning falsity; (3) the representation was intentionally made for the purpose of inducing another party to act; (4) the other party reasonably relied and acted upon the representation made; and (5) resulting in damages); Flegles, Inc. v. TruServ Corp., 289 S.W.3d 544, 548-49 (Ky. 2009) (requiring a plaintiff to prove by clear and convincing evidence that: (1) statement of material fact, (2) that was false, (3) that declarant knew to be false or made recklessly, (4) that declarant induced plaintiff to act upon the misrepresentation, (5) that plaintiff relied upon the misrepresentation, and (6) that the misrepresentation caused damages); Cowburn v. Leventis, 619 S.E.2d 437, 446 (S.C. Ct. App. 2005) (requiring clear and convincing evidence to prove fraud).

325. Worth noting is the fact that arbitration is a non-public proceeding that may or may not be transcribed or recorded. The amount and type of record in an arbitration might change from case to case, depending on the amount at stake and the financial resources of the parties involved. Proving fraud on the basis of an incomplete record may be difficult, logistically, to do. An additional constraint on the process could be issues of confidentiality, and whether the parties are even at liberty to discuss what happened at the arbitration. 
award can be vacated. ${ }^{326}$ Stated another way, plaintiffs in a civil action for fraud seek affirmative damages from the other party. The movants seeking vacatur of an arbitration award are not seeking to impose damages on the non-movant at all-they only seek to vacate an award rendered against them. ${ }^{327}$ In other words, the policy behind the heightened burden of proof does not serve the same function in the context of a motion to vacate an arbitration award as it traditionally does with respect to an affirmative claim for fraud.

Given the limitations on judicial review, ${ }^{328}$ opening up the avenue of potential criminal liability would help make the arbitral process fairer and redress wrongs that may otherwise go without redress. Extending the criminal laws of perjury and tampering to the arbitral forum would provide a needed avenue to correct misconduct in the arbitral forum, as well as provide the parties with a redress that they likely thought already existed. $^{329}$

\section{CONCLUSION}

Current perjury and tampering law does not adequately cover the arbitral forum. Almost none of the tampering laws explicitly apply to arbitration, and the perjury laws that could apply to arbitration might only apply through creative lawyering. While attorney ethics rules apply to arbitration, the criminal law has lagged behind with respect to applicability in ADR forums-particularly arbitration. This Article recommends amending the definition of "official proceeding" to include the arbitral forum. This simple legislative change would then apply the perjury, witness tampering, and evidence tampering statutes to the

326. See Lafarge Confeils Et Etudes, S.A. v. Kaiser Cement \& Gypsum Corp., 791 F.2d 1293, 1339 (9th Cir. 1986) (discussing the standard to vacate an arbitration award for fraud).

327. To be sure, some financial repercussion will result if an award is vacated. Typically, the movant seeks to vacate in order to not pay money that is awarded to the non-movant. The movant in this action typically seeks not to get money but to prevent paying out money.

328. Note, too, that parties are not free to contract for a more expansive review under the Supreme Court's 2008 decision, Hall Street Associates, LLC v. Mattel, Inc., 552 U.S. 576 (2008).

329. Arbitration participants will have to make a careful decision about when they allege this type of misconduct. Parties who are aware of the misconduct at the time of the hearing may have an obligation to bring the conduct to the attention of the arbitrator. A penalty for failure to do so may be a waiver of that defense. If the defense is brought in arbitration and then later asserted in litigation, however, then the party later asserting the defense may be estopped from bringing up the defense at that time. Further, to the extent that an arbitrator actually decides the issue, the arbitrator's finding will be subject to the limited grounds for review under the FAA or the state law counterpart. 
arbitral forum. In other words, a simple change to the definitions section would, in one fell swoop, cause three or more statutes to apply to the arbitral forum.

Sound policy underlies this recommendation. First, the perjury and tampering laws are outdated and do not consider the changing nature of arbitration-especially the changing nature of the types of claims commonly considered by arbitrators today. Second, arbitration is often considered a quasi-judicial forum. As such, the protections against perjury and tampering afforded to other quasi-judicial forums should apply to the arbitral forum. Third, courts now routinely extend absolute immunity to arbitration participants. ${ }^{330}$ This immunity makes arbitration participants immune from civil claims - such as defamation. Unless the perjury and tampering laws apply, arbitration will become a forum in which participants are ultimately immunized from both civil and criminal repercussions for misbehavior in the arbitral forum. Fourth, the marketplace, to date, has not regulated arbitration participant conduct. Extending the criminal law to the arbitral forum will fill a gap that the marketplace has left open. Finally, the limited judicial review available to arbitration parties supports the extension of the criminal law to the arbitral forum. For all of these reasons, a simple legislative change would help legitimatize arbitration as a fair forum and give participants protections against misbehavior that they might have already thought they had.

330. See supra Part III.C.4. 